\title{
Risk Assessment and Air Quality Study during Different Phases of COVID-19 Lockdown in an Urban Area of Klang Valley, Malaysia
}

\author{
Mohd Shahrul Mohd Nadzir 1,2,*iD, Mohd Zaim Mohd Nor ${ }^{3}{ }^{\mathbb{D}}$, Mohd Fadzil Firdzaus Mohd Nor ${ }^{4}(\mathbb{D}$, \\ Muhamad Ikram A Wahab ${ }^{5}$, Sawal Hamid Md Ali ${ }^{6}$ (D), Muhsin Kolapo Otuyo ${ }^{1}$, Mohd Aftar Abu Bakar ${ }^{7}$ (D), \\ Lip Huat Saw ${ }^{8}$, Shubhankar Majumdar ${ }^{9}$ (D), Maggie Chel Gee Ooi ${ }^{10}$, Faizal Mohamed ${ }^{11}$, Badrul Akmal Hisham ${ }^{12}$, \\ Haris Hafizal Abd Hamid ${ }^{1}$, Zaki Khaslan ${ }^{1}$, Noratiqah Mohd Ariff ${ }^{7}$ (D), Johary Anuar ${ }^{13}$, Gee Ren Tok ${ }^{1}$, \\ Nurul Asyikin Ya'akop ${ }^{1}$ and Mai'izzati Mohd Meswan ${ }^{1}$
}

Citation: Mohd Nadzir, M.S.; Mohd Nor, M.Z.; Mohd Nor, M.F.F.; A Wahab, M.I.; Ali, S.H.M.; Otuyo, M.K.; Abu Bakar, M.A.; Saw, L.H.; Majumdar, S.; Ooi, M.C.G.; et al. Risk Assessment and Air Quality Study during Different Phases of COVID-19 Lockdown in an Urban Area of Klang Valley, Malaysia. Sustainability 2021, 13, 12217. https://doi.org/10.3390/ su132112217

Academic Editor: Li Li

Received: 9 August 2021

Accepted: 22 October 2021

Published: 5 November 2021

Publisher's Note: MDPI stays neutral with regard to jurisdictional claims in published maps and institutional affiliations.

Copyright: (c) 2021 by the authors. Licensee MDPI, Basel, Switzerland. This article is an open access article distributed under the terms and conditions of the Creative Commons Attribution (CC BY) license (https:// creativecommons.org/licenses/by/ $4.0 /)$
1 Department of Earth Sciences and Environment, Faculty of Science and Technology, Universiti Kebangsaan Malaysia, Bangi 43600, Selangor, Malaysia; p108956@siswa.ukm.edu.my (M.K.O.); haris@ukm.edu.my (H.H.A.H.); zakikhaslan@gmail.com (Z.K.); a166085@siswa.ukm.edu.my (G.R.T.); syikinyaakop1@gmail.com (N.A.Y.); a163628@siswa.ukm.edu.my (M.M.M.)

2 Centre for Tropical System and Climate Change (IKLIM), Institute of Climate Change, Universiti Kebangsaan Malaysia, Bangi 43600, Selangor, Malaysia

3 Petaling Jaya City Council, Jalan Yong Shook Lin, Petaling Jaya 46675, Selangor, Malaysia; mohdzaim@mbpj.gov.my

4 Institute of Ocean \& Earth Sciences, C308 IAS Building, University Malaya, Kuala Lumpur 50603, Malaysia; fadzil.mnor@um.edu.my

5 Environmental Health and Industrial Safety Program, Faculty of Health Sciences, School of Diagnostic Science and Applied Health, Universiti Kebangsaan Malaysia, Jalan Raja Muda Abdul Aziz, Kuala Lumpur 50300, Malaysia; ikram@ukm.edu.my

6 Department of Electrical, Electronic and Systems Engineering, Faculty of Engineering and Built Environment, Universiti Kebangsaan Malaysia, Bangi 43600, Selangor, Malaysia; sawal@ukm.edu.my

7 Department of Mathematical Sciences, Faculty of Science and Technology, Universiti Kebangsaan Malaysia, Bangi 43600, Selangor, Malaysia; aftar@ukm.edu.my (M.A.A.B.); tqah@ukm.edu.my (N.M.A.)

8 Lee Kong Chian, Faculty of Engineering and Science, Universiti Tunku Abdul Rahman, Kajang 43000, Selangor, Malaysia; sawlh@utar.edu.my

9 Department of Electronics and Communication Engineering, National Institute of Technology Meghalaya, Shillong 793003, India; shub@nitm.ac.in

10 Earth Observatory Center, Institute of Climate Change, Universiti Kebangsaan Malaysia, Bangi 43600, Selangor, Malaysia; chelgee.ooi@ukm.edu.my

11 Faculty of Science and Technology, School of Applied Physics, Universiti Kebangsaan Malaysia, Bangi 43600, Selangor, Malaysia; faizalm@ukm.edu.my

12 Department of Orthopedics \& Traumatology, Faculty of Medicine, Universiti Kebangsaan Malaysia, Jalan Yaacob Latif, Bandar Tun Razak, Cheras, Kuala Lumpur 56000, Malaysia; badortho@gmail.com

13 Petaling District and Land Office Complex Shah, Shah Alam 40150, Selangor, Malaysia; johary@selangor.gov.my

* Correspondence: shahrulnadzir@ukm.edu.my

Abstract: Globally, the COVID-19 pandemic has had both positive and negative impacts on humans and the environment. In general, a positive impact can be seen on the environment, especially in regard to air quality. This positive impact on air quality around the world is a result of movement control orders (MCO) or lockdowns, which were carried out to reduce the cases of COVID-19 around the world. Nevertheless, data on the effects on air quality both during and post lockdown at local scales are still sparse. Here, we investigate changes in air quality during normal days, the MCOs (MCO 1, 2 and 3) and post MCOs, namely the Conditional Movement Control Order (CMCO) and the Recovery Movement Control Order (RMCO) in the Klang Valley region. In this study, we used the air sensor network AiRBOXSense that measures carbon monoxide (CO), nitrogen dioxide $\left(\mathrm{NO}_{2}\right)$, sulfur dioxide $\left(\mathrm{SO}_{2}\right)$ and particulate matter $\left(\mathrm{PM}_{2.5}\right.$ and $\left.\mathrm{PM}_{10}\right)$ at Petaling Jaya South (PJS), Kelana Jaya $(\mathrm{KJ})$ and Kota Damansara (KD). The results showed that the daily average concentrations of $\mathrm{CO}$ and $\mathrm{NO}_{2}$ mostly decreased in the order of normal days $>$ MCO (MCO 1, 2 and 3) $>$ CMCO $>$ RMCO. $\mathrm{PM}_{10}, \mathrm{PM}_{2.5}, \mathrm{SO}_{2}$ and $\mathrm{O}_{3}$ showed a decrease from the MCO to RMCO. PJS showed that air pollutant 
concentrations decreased from normal days to the lockdown phases. This clearly shows the effects of 'work from home' orders at all places in the PJS city. The greatest percentage reductions in air pollutants were observed during the change from normal days to MCO 1 ( $24 \%$ to $64 \%$ ), while during MCO 1 to MCO 2, the concentrations were slightly increased during the changes of the lockdown phase, except for $\mathrm{SO}_{2}$ and $\mathrm{NO}_{2}$ over PJS. In $\mathrm{KJ}$, most of the air pollutants decreased from MCO 1 to $\mathrm{MCO} 3$ except for $\mathrm{CO}$. However, the percentage reduction and increments of the gas pollutants were not consistent during the different phases of lockdown, and this effect was due to the sensor locationonly $20 \mathrm{~m}$ from the main highway (vehicle emissions). The patterns of air pollutant concentrations over the KD site were similar to the PJS site; however, the percentage reduction and increases of $\mathrm{PM}_{2.5}, \mathrm{O}_{3}, \mathrm{SO}_{2}$ and $\mathrm{CO}$ were not consistent. We believe that local burning was the main contribution to these unstable patterns during the lockdown period. The cause of these different changes in concentrations may be due to the relaxation phases during the lockdown at each station, where most of the common activities, such as commuting and industrial activities changed in frequency from the $\mathrm{MCO}, \mathrm{CMCO}$ and RMCO. Wind direction also affected the concentrations, for example, during the $\mathrm{CMCO}$ and RMCO, most of the pollutants were blowing in from the Southeast region, which mostly consists of a city center and industrial areas. There was a weak correlation between air pollutants and the temperature and relative humidity at all stations. Health risk assessment analysis showed that non-carcinogenic risk health quotient (HQ) values for the pollutants at all stations were less than 1, suggesting unlikely non-carcinogenic effects, except for $\mathrm{SO}_{2}(\mathrm{HQ}>1)$ in $\mathrm{KJ}$. The air quality information showed that reductions in air pollutants can be achieved if traffic and industry emissions are strictly controlled.

Keywords: movement control orders (MCO) phases; air quality; low-cost air quality sensor (LAQS)

\section{Introduction}

The COVID-19 pandemic caused by the SARS-CoV-2 virus resulted in over 4.7 million deaths along with many losing their source of income and various other negative effects. Ambient air pollutants, such as carbon monoxide $(\mathrm{CO})$, sulfur dioxide $\left(\mathrm{SO}_{2}\right)$, nitrogen dioxide $\left(\mathrm{NO}_{2}\right)$, ozone and particulate matter $\left(\mathrm{PM}_{10}\right.$ and $\left.\mathrm{PM}_{2.5}\right)$, are common air pollutants measured by many countries as they represent the status of ambient air quality. Poor air quality can result in various human health issues, such as respiratory problems and carcinogenic effects [1-4].

However, despite the many negative effects of the pandemic, there have also been positive effects, such as the impacts on the environment. In an attempt to control the spread of the virus, many countries worldwide, including Malaysia, enforced lockdowns, also known as Movement Control Orders (MCOs), which inadvertently caused some positive changes to the environment [5-7]. Many countries have recorded cleaner air quality readings as a result of these lockdowns [7-10].

Air quality measurements have been carried out by air quality monitoring networks and satellite observations to determine the extent to which air quality levels changed during the lockdowns implemented in most countries. For example, previous observations showed that these air pollutants were significantly decreased throughout whole continents and countries, such as the United States [11], Asia [12], Europe [13] and Australia [14]. In Malaysia, studies have been conducted and showed similar results $[4,5,9,12,13]$. The air quality measurements also differed in each study.

Observations by using satellite observations in Europe showed that the $\mathrm{NO}_{2}$ tropospheric column concentrations showed a decrease of $-20 \%$ to $-38 \%$ [14]. A study using surface observations and machine learning to retrieve the $\mathrm{NO}_{2}$ concentration data during lockdown showed that the lockdowns were responsible for a decrease of $50 \% \mathrm{NO}_{2}$ [15]. Observations using data from the European Commission Atmospheric Observatory of Ispra (regional background) and from the regional environmental protection agency (ARPA) air monitoring stations in Milan showed $\mathrm{NO}_{2}$ concentrations decreased due to the lockdowns 
by $-30 \%$ and $-40 \%$ on average at the urban and regional levels, respectively [16]. The study also used forecast model data from the Copernicus Atmosphere Monitoring Service (CAMS), which indicated similar reductions of $\mathrm{NO}_{2}$ concentrations as a consequence of the lockdowns of $-30 \%$ and $-40 \%$ on average at the urban and regional background sites, respectively [16].

In Malaysia, studies by $[9,12]$ used observation data from reference monitoring stations owned by the Department of Environment Malaysia (DOE). However, the use of air quality sensor networks for the identification of a reduction in air pollutants is still absent. Observations using the low-cost air quality sensor (LAQS) network in Klang Valley showed a more than $50 \%$ reduction of $\mathrm{PM}_{10}, \mathrm{PM}_{2.5}$ and $\mathrm{CO}$ during $\mathrm{MCO} 1$ [5]. However, the $\mathrm{PM}_{10}$, $\mathrm{PM}_{2.5}$ and $\mathrm{CO}$ air pollutant data were limited and only monitored during MCO 1. Thus, this study will continue the previous observations [5].

In the current study, the air pollutants measured were $\mathrm{CO}, \mathrm{NO}_{2}, \mathrm{SO}_{2}, \mathrm{O}_{3}, \mathrm{PM}_{10}$ and $\mathrm{PM}_{2.5}$ over an urban area of the Klang Valley, during normal days and different phases of the lockdown period, using the LAQS. The meteorological and wind trajectory influences were evaluated using ERA5 data. Finally, this study will provide information on the health risks associated with these air pollutants and provide evidence-based knowledge for formulating achievable air quality management strategies for pollution control.

\section{Methodology}

\subsection{Low-Cost Air Quality Sensor Deployment}

Details of the AiRBOXSense system have been published in a previous work [17]. The specific requirements of AiRBOXSense were reliability and durability while being low cost, portable and easy to install by the user. AiRBOXSense collects, analyses and shares air quality data using a wireless communication network [17]. Using the Internet of Things (IoT) allows data to be sent to remote cloud storage, such as Thingspeak, periodically as well as providing near-real-time visualization of numerical and graphical values over time. The electrochemical sensor (EC) for $\mathrm{CO}, \mathrm{NO}_{2}, \mathrm{SO}_{2}$ and $\mathrm{O}_{3}$ and the optical particle sensor (OPC-N2) for PM measurements were manufactured by Alphasense (Alphasense Ltd., Great Notley, Braintree, UK).

The uncertainties (based on uncorrected and standard gas mixing ratios) of each of the sensors were $\pm 2 \mathrm{ppb}, \pm 2 \mathrm{ppb}, \pm 1.5 \mathrm{ppb}, \pm 2 \mathrm{ppb}$ and $\pm 3.2 \mathrm{ppb}$ for $\mathrm{CO}, \mathrm{NO}_{2}, \mathrm{SO}_{2}, \mathrm{O}_{3}$ and $\mathrm{PM}\left(\mathrm{PM}_{2.5}\right.$ and $\left.\mathrm{PM}_{10}\right)$, respectively. Details of the AiRBOXSense calibration, configuration and operation were described in our previous work [17]. Three AiRBOXSense sensors were deployed at locations in Petaling Jaya South (PJS), Kelana Jaya (KJ) and Kota Damansara (KD) (see Figure 1).

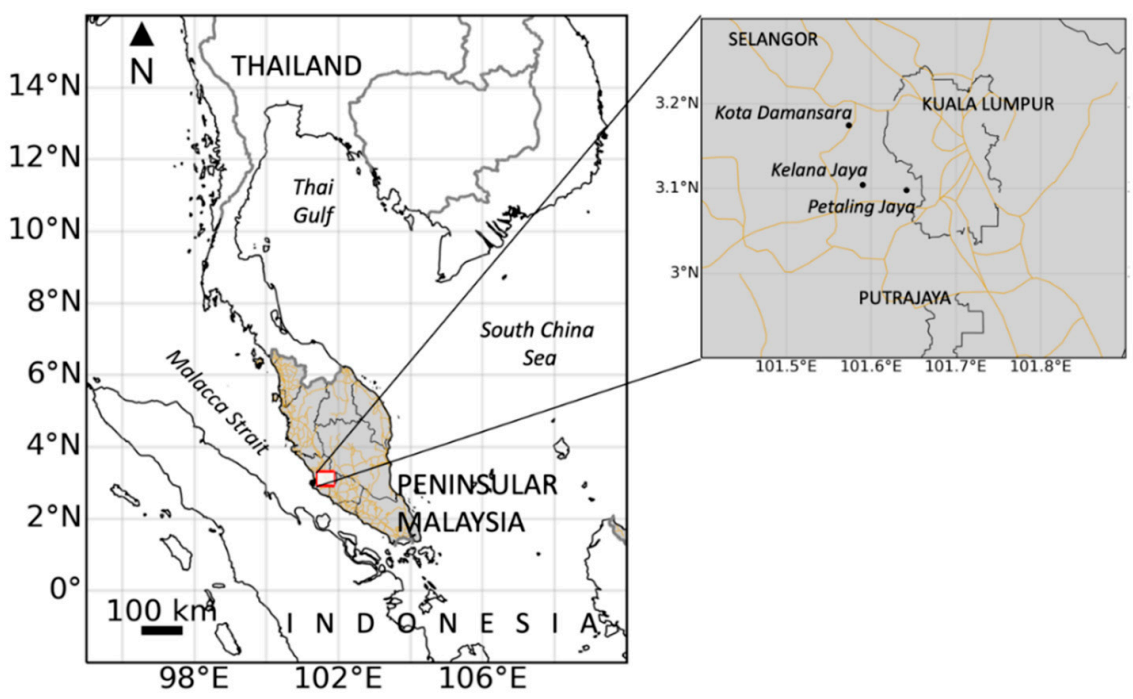

Figure 1. Location of the sensor units. 


\section{2. $M C O, C M C O$ and $R M C O$}

In Malaysia, the Malaysian government ordered the first Movement Control Order (MCO) on 18 March 2020 as shown in Table 1. This was later extended and then relaxed to different phases known as the Conditional Movement Control Order (CMCO) and Recovery Movement Control Order (RMCO). The MCO started on 18 March and continued to 3 May 2020; the CMCO started on 4 May, continuing until 9 June 2020; and the RMCO started on 10 June 2020, continuing until 31 March 2021. The MCO can be seen as an unplanned air quality experiment to study the effects on air quality of extraordinary reductions in anthropogenic activities. Furthermore, MCOs may help to identify an air quality baseline target to achieve in normal conditions.

Table 1. Lockdown phases in Malaysia.

\begin{tabular}{cc}
\hline Movement Control Order (MCO), 18 March 2020-3 May 2020 \\
\hline Phase & Date \\
\hline Phase 1 & 18 March 2020-31 March 2020 \\
\hline Phase 2 & 1 April 2020-14 April 2020 \\
\hline Phase 3 & 15 April 2020-28 April 2020 \\
\hline Phase 4 & 29 April 2020-3 May 2020 \\
\hline Conditional Movement Control Order (CMCO), 4 May 2020-9 June 2020 \\
\hline Phase 1 & 4 May 2020-12 May 2020 \\
\hline Phase 2 & 13 May 2020-9 June 2020 \\
\hline Recovery Movement Control Order (RMCO), 10 June 2020-31 March 2021 \\
\hline Phase 1 & 10 June 2020-31 August 2020 \\
\hline Phase 2 & 1 September 2020-31 December 2020 \\
\hline Phase 3 & 1 January 2021-31 March 2021 \\
\hline MCO 2 by states, 11 January 2021-31 May 2021 & \\
\hline Each state switched between MCO, CMCO, RMCO \\
\hline MCO 3, 1 June 2021-28 June 2021 \\
\hline Enhanced Movement Control Order (EMCO), 3 July 2021 onwards
\end{tabular}

The main restriction imposed during MCO was the general prohibition of large gatherings and daily activities across the nation and the closure of all government and private premises except for essential services [4]. The MCO later transitioned to the CMCO, with slightly more relaxed restrictions that allowed the resumption of most economic sectors and interstate travel for work purposes only [18]. The RMCO was later introduced with more relaxed restrictions, considering the downward trend of daily COVID-19 cases at the time. The implementation of the RMCO saw the resumption of daily activities while abiding to social distancing protocols and interstate travel was allowed, except for areas under an Enhanced Movement Control Order (EMCO). An EMCO is implemented in specific locations with a high infection rate and, hence, consists of much more stringent restrictions whereby such areas are completely closed off for non-residents.

\subsection{Meteorological Parameters}

The temperature and relative humidity $(\mathrm{RH})$ were measured using AiRBOXSense. The sensor probes for temperature and RH were AF5485 sensors (SEEED, China). Wind data was obtained from the European Centre for Medium-Range Weather Forecasts (ECMWF) via the toolbox on the Copernicus Climate Change Service website [19]. The wind speed was at $10 \mathrm{~m}$ at about ground level with a time resolution of one hour and a horizontal resolution of $1.5^{\circ} \times 1.5^{\circ}$. As the three stations are close together, they are all within the same $1.5^{\circ}$ grid area and, hence, have the same wind speeds and directions. 


\section{Results and Discussion}

\subsection{Wind Pattern during MCO, RMCO, MCO 2 and MCO 3}

Previous air pollutant concentration studies in Klang Valley, Malaysia have shown that the reduction in motor vehicles on the roads was the main cause of changes during the MCO compared to the influences from meteorological factors $[5,9,12]$. In addition, a study showed weak correlations between air pollutant concentrations and meteorological factors in the Klang Valley [20]. However, it is worth studying the correlations between meteorological factors and air pollutant concentrations during different phases of the MCO. In this study, we will consider the correlations of meteorological factors, such as the temperature and relative humidity, which will be discussed in Section 3.5.

The wind speed and direction showed different patterns during the different lockdown phases. Most of the winds were from the south-east (SE) during the lockdown over the Petaling Jaya areas as shown in Figure 2. The air pollutants were expected to originate from the Kuala Lumpur (KL) region, which is the capital of Malaysia, Seri Kembangan (SB) and Puchong. The pollutant concentrations were mostly affected by vehicular and industrial emissions.
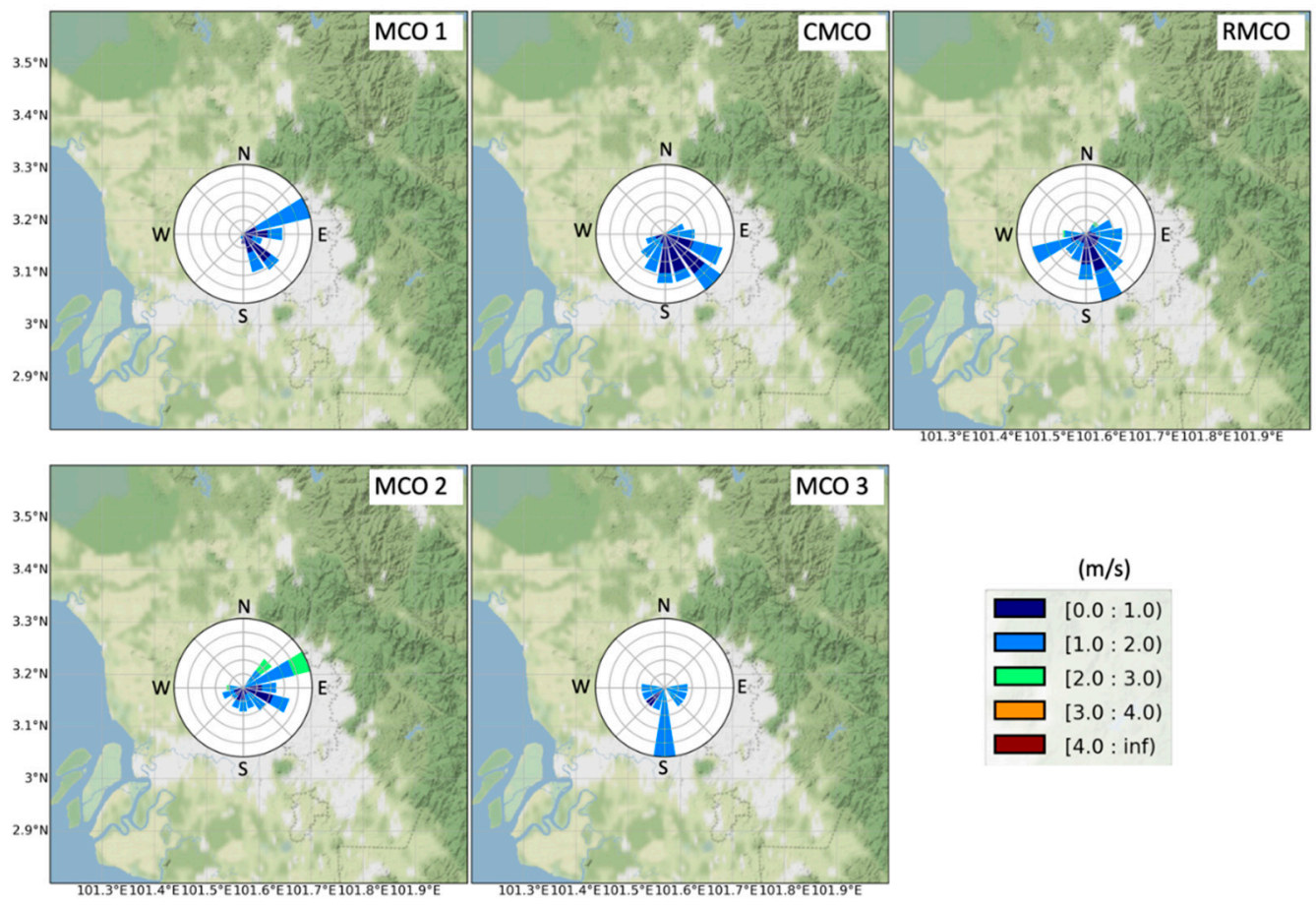

Figure 2. Windroses showing the frequency (\%) of wind direction during each lockdown phase.

The KL area mainly experiences a combination of vehicular and industrial emissions, while SB and Puchong are mainly heavy industrial areas. During CMCO and RMCO, the winds were mostly from a southerly direction, from SB and Puchong areas. During MCO 2, the wind speed increased to $3.0 \mathrm{~ms}^{-1}$ but the wind directions were from the SE, which is similar to the MCO period. During the MCO 3, wind directions were from the Putrajaya area.

\subsection{Sensor Data}

\subsubsection{Petaling Jaya South (PJS)}

In this study, only normal day data was available for the PJS station. Table 2, Figure 3a-f how the average daily concentrations data and time series of measured air pollutants over the PJS area. These observations were similar to the previous study by [5] in the same region. The daily averages of $\mathrm{PM}_{10}$ and $\mathrm{PM}_{2.5}$ during normal days were $21.68 \mu \mathrm{gm}^{-3}$ and 
$10.4 \mathrm{\mu gm}^{-3}$, respectively. The highest maximum concentration was recorded for $\mathrm{CO}$ with a maximum value of $1191.08 \mathrm{ppb}$.

Table 2. Daily concentrations of $\mathrm{PM}_{10}, \mathrm{PM}_{2.5}, \mathrm{SO}_{2}, \mathrm{NO}_{2}, \mathrm{O}_{3}$ and $\mathrm{CO}$ over PJS (note: unit for PM is in $\mu \mathrm{gm}^{-3}, \mathrm{SO}_{2}, \mathrm{NO}_{2}, \mathrm{O}_{3}$ and $\mathrm{CO}$ are in $\left.\mathrm{ppb}\right)$.

\begin{tabular}{|c|c|c|c|c|c|c|}
\hline \multicolumn{7}{|c|}{ Normal } \\
\hline & $\mathrm{PM}_{10}$ & $\mathrm{PM}_{2.5}$ & $\mathrm{SO}_{2}$ & $\mathrm{NO}_{2}$ & $\mathrm{O}_{3}$ & $\mathrm{CO}$ \\
\hline $\min$ & 10.0 & 3.9 & 20.7 & 6.3 & 16.7 & 245.7 \\
\hline $\max$ & 39.2 & 23.9 & 78.7 & 40.7 & 76.8 & 1191.0 \\
\hline average & 21.7 & 10.4 & 42.4 & 18.1 & 53.5 & 546.7 \\
\hline \multicolumn{7}{|c|}{ MCO 1} \\
\hline & $\mathrm{PM}_{10}$ & $\mathrm{PM}_{2.5}$ & $\mathrm{SO}_{2}$ & $\mathrm{NO}_{2}$ & $\mathrm{O}_{3}$ & $\mathrm{CO}$ \\
\hline $\min$ & 5.9 & 2.3 & 20.2 & 6.8 & 38.3 & 196.9 \\
\hline $\max$ & 17.4 & 9.4 & 35.4 & 27.6 & 58.0 & 418.1 \\
\hline average & 11.1 & 5.5 & 28.6 & 14.5 & 49.7 & 300.4 \\
\hline \multicolumn{7}{|c|}{$\mathrm{CMCO}$} \\
\hline & $\mathrm{PM}_{10}$ & $\mathrm{PM}_{2.5}$ & $\mathrm{SO}_{2}$ & $\mathrm{NO}_{2}$ & $\mathrm{O}_{3}$ & $\mathrm{CO}$ \\
\hline $\min$ & 7.1 & 2.9 & 17.0 & 7.4 & 33.1 & 230.6 \\
\hline $\max$ & 24.4 & 11.5 & 33.5 & 26.7 & 58.3 & 549.2 \\
\hline average & 11.4 & 5.5 & 23.3 & 14.8 & 48.0 & 351.7 \\
\hline \multicolumn{7}{|c|}{ RMCO } \\
\hline & $\mathrm{PM}_{10}$ & $\mathrm{PM}_{2.5}$ & $\mathrm{SO}_{2}$ & $\mathrm{NO}_{2}$ & $\mathrm{O}_{3}$ & $\mathrm{CO}$ \\
\hline $\min$ & 5.4 & 2.1 & 6.8 & 6.4 & 29.2 & 227.0 \\
\hline $\max$ & 23.9 & 12.1 & 48.5 & 53.7 & 68.7 & 890.7 \\
\hline average & 11.8 & 5.4 & 19.7 & 18.9 & 46.8 & 411.4 \\
\hline \multicolumn{7}{|c|}{ MCO 2} \\
\hline & $\mathrm{PM}_{10}$ & $\mathrm{PM}_{2.5}$ & $\mathrm{SO}_{2}$ & $\mathrm{NO}_{2}$ & $\mathrm{O}_{3}$ & $\mathrm{CO}$ \\
\hline $\min$ & 5.45 & 2.32 & 10.51 & 224.15 & 38.54 & 6.77 \\
\hline $\max$ & 15.61 & 8.59 & 33.47 & 718.14 & 70.37 & 38.63 \\
\hline average & 10.37 & 5.12 & 22.92 & 60.25 & 51.16 & 17.49 \\
\hline
\end{tabular}

Meanwhile, the $\mathrm{O}_{3}, \mathrm{NO}_{2}$ and $\mathrm{SO}_{2}$ daily averages were $53.51 \mathrm{ppb}, 18.11 \mathrm{ppb}$ and $78.70 \mathrm{ppb}$, respectively. However, $\mathrm{PM}_{2.5}$ and $\mathrm{PM}_{10}$ recorded decreases from MCO 1 to RMCO to MCO 2, while $\mathrm{NO}_{2}$ and $\mathrm{O}_{3}$ concentrations increased from MCO 1 to RMCO to MCO 2. All pollutant concentrations were still below the Malaysian Ambient Air Quality Standards (MAAQS) air quality guideline values except for $\mathrm{NO}_{2}$, which was high during RMCO with recorded a daily average of $53.7 \mathrm{ppb}$ (MAAQS daily average is $42.5 \mathrm{ppb}$, as shown in Table 3). 


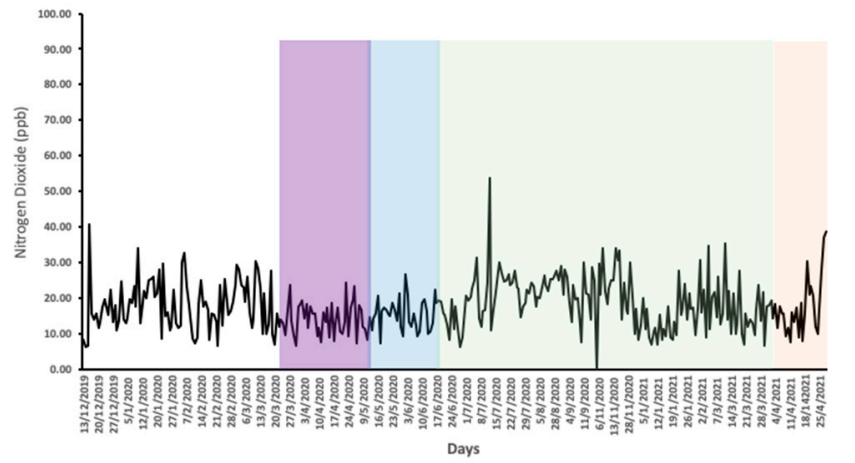

(a)

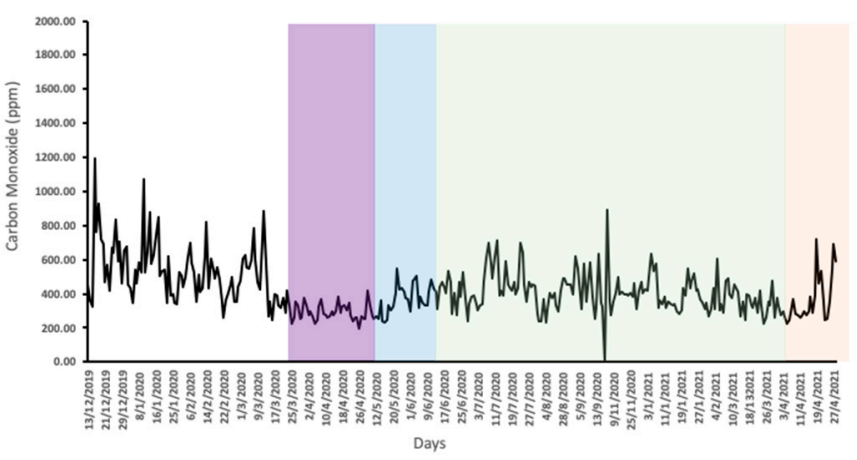

(c)

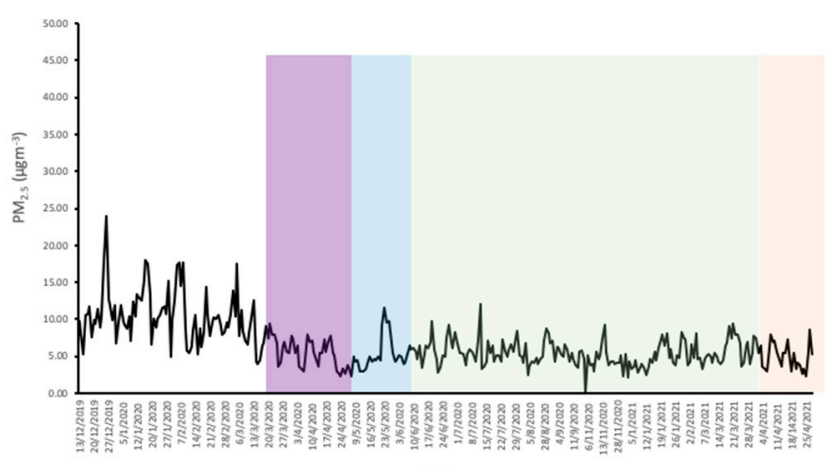

(e)

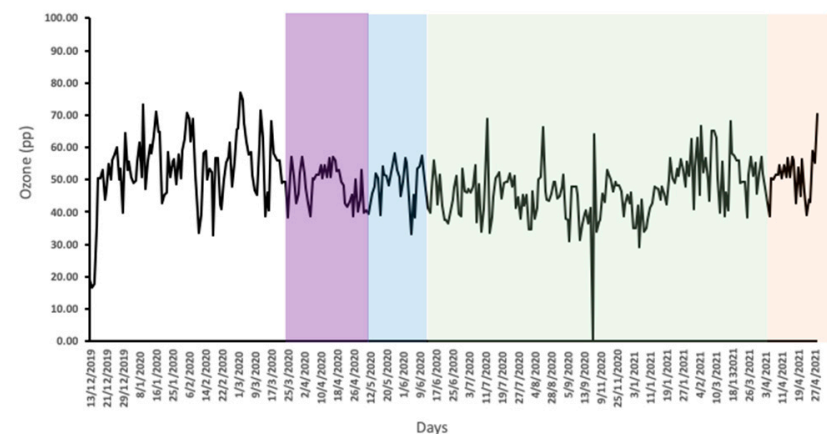

(b)

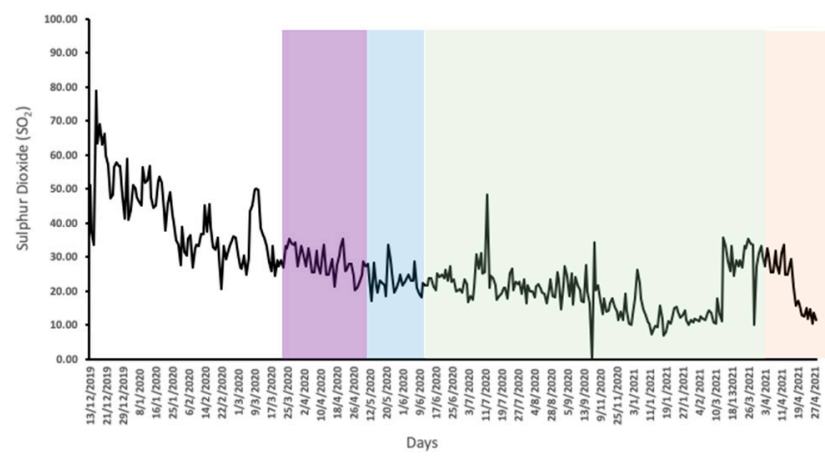

(d)

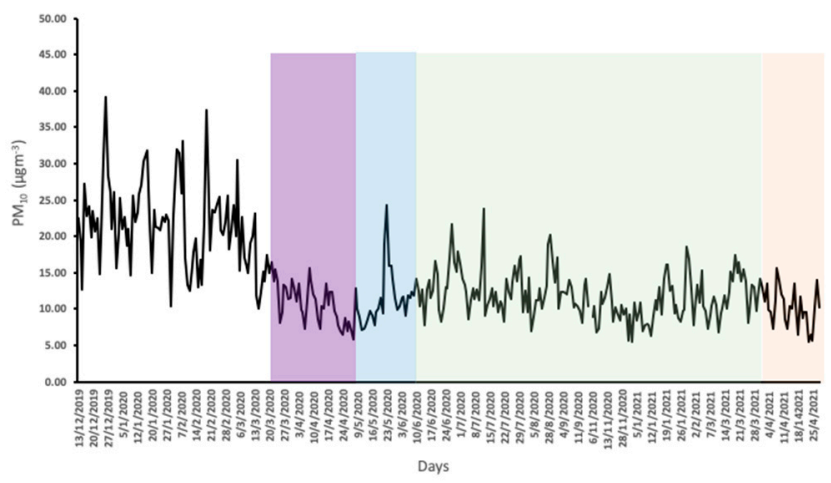

(f)

Figure 3. (a-f). Daily concentration of (a) $\mathrm{NO}_{2}$, (b) $\mathrm{O}_{3}$, (c) $\mathrm{CO}$, (d) $\mathrm{SO}_{2}$, (e) $\mathrm{PM}_{2.5}$ and (f) $\mathrm{PM}_{10}$ during normal days, $\mathrm{MCO}$ 1, CMCO, RMCO, MCO 2 over PJS. (Note: color bands represent different phases, white (normal), purple (MCO 1), blue (CMCO), green (RMCO) and orange (MCO 2).

During MCO 1, most of the pollutant concentrations showed significant reductions compared to the normal days as shown in Table 4. These observations were also shown by $[9,21]$ to be due to the decreased number of vehicles and the temporary closure of industries during the MCO in Malaysia. During CMCO, air pollutant concentrations increased by $40.3 \%, 22.9 \%, 5.51 \%, 3.22 \%, 0.41 \%$ and $31.3 \%$ for $\mathrm{PM}_{10}, \mathrm{PM}_{2.5}, \mathrm{SO}_{2}, \mathrm{NO}_{2}, \mathrm{O}_{3}$ and $\mathrm{CO}$, respectively. These observations can be expected from the increased numbers of vehicles and industries operating during this period. Meanwhile, during RMCO, small increases were seen during this period (see Table 4). During RMCO, most activities were allowed by the government, which led to the increment of the pollutant concentrations. 
Table 3. Malaysian Ambient Air Quality Standards (MAAQS) values ( $24 \mathrm{~h}$ averaging time) (note: n.a. = not available).

\begin{tabular}{ccc}
\hline Pollutants & Averaging Time & MAAQS \\
\hline $\mathrm{PM}_{10}$ & $24 \mathrm{~h}$ & $50 \mu \mathrm{gm}^{-3}$ \\
\hline $\mathrm{PM}_{2.5}$ & $24 \mathrm{~h}$ & $25 \mu \mathrm{gm}^{-3}$ \\
\hline $\mathrm{SO}_{2}$ & $24 \mathrm{~h}$ & $30.5 \mathrm{ppb}$ \\
\hline $\mathrm{NO}_{2}$ & $24 \mathrm{~h}$ & $42.5 \mathrm{ppb}$ \\
\hline $\mathrm{O}_{3}$ & $24 \mathrm{~h}$ & n.a. \\
\hline $\mathrm{CO}$ & $24 \mathrm{~h}$ & n.a. \\
\hline
\end{tabular}

Table 4. Percentage increase and reduction of pollutants during normal days to MCO, MCO to RMCO and RMCO to CMCO over PJS (note: - reduction and + increase).

\begin{tabular}{cccccccc}
\hline \multicolumn{2}{c}{ Normal-MCO } & \multicolumn{2}{c}{ MCO-CMCO } & \multicolumn{2}{c}{ CMCO-RMCO } & \multicolumn{2}{c}{ RMCO-MCO 2 } \\
\hline \multicolumn{2}{c}{ Percentage $\%$} & \multicolumn{2}{c}{ Percentage $\%$} & \multicolumn{2}{c}{ Percentage $\%$} & \multicolumn{2}{c}{ Percentage \% } \\
\hline $\mathrm{PM}_{10}$ & -55.74 & $\mathrm{PM}_{10}$ & +40.25 & $\mathrm{PM}_{10}$ & +2.03 & $\mathrm{PM}_{10}$ & +12.4 \\
\hline $\mathrm{PM}_{2.5}$ & -60.86 & $\mathrm{PM}_{2.5}$ & +22.91 & $\mathrm{PM}_{2.5}$ & +5.55 & $\mathrm{PM}_{2.5}$ & +5.79 \\
\hline $\mathrm{SO}_{2}$ & -55.03 & $\mathrm{SO}_{2}$ & +5.51 & $\mathrm{SO}_{2}$ & +44.56 & $\mathrm{SO}_{2}$ & -15.94 \\
\hline $\mathrm{NO}_{2}$ & -32.24 & $\mathrm{NO}_{2}$ & +3.22 & $\mathrm{NO}_{2}$ & +10.78 & $\mathrm{NO}_{2}$ & -8.05 \\
\hline $\mathrm{O}_{3}$ & -24.37 & $\mathrm{O}_{3}$ & +0.41 & $\mathrm{O}_{3}$ & +17.83 & $\mathrm{O}_{3}$ & +8.53 \\
\hline $\mathrm{CO}$ & -64.90 & $\mathrm{CO}$ & +31.34 & $\mathrm{CO}$ & +62.20 & $\mathrm{CO}$ & +12.44 \\
\hline
\end{tabular}

\subsubsection{Kelana Jaya}

Table 5, Figures 4 and 5 show the average daily concentrations data and time series of measured air pollutants over the $\mathrm{KJ}$ area. The daily averages of $\mathrm{PM}_{10}$ and $\mathrm{PM}_{2.5}$ during normal days were $11.07 \mathrm{\mu gm}^{-3}$ and $5.62 \mathrm{\mu gm}^{-3}$, respectively. The highest maximum concentration was recorded for $\mathrm{CO}$ with a maximum of $452.49 \mathrm{ppb}$. The daily average concentrations for $\mathrm{O}_{3}, \mathrm{NO}_{2}$ and $\mathrm{SO}_{2}$ were $49.13 \mathrm{ppb}, 29.24 \mathrm{ppb}$ and $43.28 \mathrm{ppb}$, respectively. Even so, all pollutant concentrations were still below the MAAQS values, except for $\mathrm{SO}_{2}$, which recorded a high daily average reading of $77.43 \mathrm{ppb}$ (MAAQS daily average is $30.5 \mathrm{ppb}$, as shown in Table 3).

During MCO 1, most pollutant concentrations showed a decrease transitioning from the MCO to CMCO, as shown in Table 6. The concentrations decreased by $0.58 \%, 13.81 \%$, $5.23 \%$ and $15.63 \%$ for $\mathrm{PM}_{10}, \mathrm{PM}_{2.5}, \mathrm{SO}_{2}$ and $\mathrm{O}_{3}$, respectively, whereas an increase was observed for both $\mathrm{NO}_{2}$ and $\mathrm{CO}$ at $0.79 \%$ and $65.74 \%$, respectively. Such results show that there was an increase in traffic during the transition, which led to the $\mathrm{NO}_{2}$ and $\mathrm{CO}$ increases from the $\mathrm{MCO}$ to $\mathrm{CMCO}$ in $\mathrm{KJ}$, as these are the main pollutants of vehicular emissions from the Damansara-Puchong Highway (LDP) where the AiRBOXSense was located ( 30 m from LDP).

At the same time, the reductions in $\mathrm{PM}_{10}, \mathrm{PM}_{2.5}, \mathrm{SO}_{2}$ and $\mathrm{O}_{3}$ show that businesses and residents in Kelana Jaya were still in the process of transitioning by adhering to the standard operating procedure (SOP) and remaining at their homes and premises. During the RMCO, a significant decrease was observed at $78.47 \%, 64.19 \%, 30.36 \%$ and $29.01 \%$ for $\mathrm{PM}_{10}, \mathrm{PM}_{2.5}, \mathrm{SO}_{2}$ and $\mathrm{NO}_{2}$, respectively, whereas $\mathrm{O}_{3}$ and $\mathrm{CO}$ showed an increase of $29.51 \%$ and $7.91 \%$, respectively. Even though, during the RMCO, the numbers of vehicles and operational industries were expected to increase, the majority of industries were still implementing a work from home (WFH) policy for their staff. The observed decreases in $\mathrm{PM}_{10}, \mathrm{PM}_{2.5}, \mathrm{SO}_{2}$ and $\mathrm{NO}_{2}$ during the RMCO can be seen as an attempt by the local people to stay safe, even after the restrictions were relaxed by the government, consequently, contributing to the decreased activity and usage of vehicles. 
Table 5. Daily concentrations of $\mathrm{PM}_{10}, \mathrm{PM}_{2.5}, \mathrm{SO}_{2}, \mathrm{NO}_{2}, \mathrm{O}_{3}$ and $\mathrm{CO}$ over $\mathrm{KJ}$. (Note: unit for PM is in $\mu \mathrm{gm}^{-3}, \mathrm{SO}_{2}, \mathrm{NO}_{2}, \mathrm{O}_{3}$ and $\mathrm{CO}$ are in $\left.\mathrm{ppb}\right)$.

\begin{tabular}{|c|c|c|c|c|c|c|}
\hline \multicolumn{7}{|c|}{ MCO } \\
\hline & $\mathbf{P M}_{10}$ & $\mathbf{P M}_{2.5}$ & $\mathrm{SO}_{2}$ & $\mathrm{NO}_{2}$ & $\mathrm{O}_{3}$ & $\mathrm{CO}$ \\
\hline $\min$ & 6.73 & 2.26 & 30.92 & 15.28 & 29.64 & 213.48 \\
\hline $\max$ & 28.10 & 19.14 & 77.43 & 46.22 & 77.93 & 452.49 \\
\hline average & 11.07 & 5.62 & 43.28 & 29.24 & 49.13 & 297.20 \\
\hline \multicolumn{7}{|c|}{ CMCO } \\
\hline & $\mathbf{P M}_{10}$ & $\mathbf{P M}_{2.5}$ & $\mathrm{SO}_{2}$ & $\mathrm{NO}_{2}$ & $\mathrm{O}_{3}$ & $\mathrm{CO}$ \\
\hline $\min$ & 0.21 & 16.49 & 33.21 & 23.73 & 33.11 & 261.40 \\
\hline $\max$ & 27.93 & 0.17 & 73.39 & 46.58 & 65.75 & 885.69 \\
\hline average & 7.44 & 3.85 & 43.69 & 36.10 & 48.35 & 418.03 \\
\hline \multicolumn{7}{|c|}{ RMCO } \\
\hline & $\mathbf{P M}_{10}$ & $\mathbf{P M}_{2.5}$ & $\mathrm{SO}_{2}$ & $\mathrm{NO}_{2}$ & $\mathrm{O}_{3}$ & $\mathrm{CO}$ \\
\hline $\min$ & 0.05 & 0.04 & 33.95 & 23.64 & 23.91 & 213.59 \\
\hline $\max$ & 6.01 & 5.91 & 51.11 & 65.62 & 85.15 & 955.72 \\
\hline average & 0.95 & 0.93 & 41.84 & 40.33 & 44.58 & 480.82 \\
\hline \multicolumn{7}{|c|}{ MCO 2} \\
\hline & $\mathbf{P M}_{10}$ & $\mathbf{P M}_{2.5}$ & $\mathrm{SO}_{2}$ & $\mathrm{NO}_{2}$ & $\mathrm{O}_{3}$ & $\mathrm{CO}$ \\
\hline $\min$ & 0.09 & 0.09 & 14.72 & 23.64 & 23.91 & 223.20 \\
\hline $\max$ & 6.01 & 5.91 & 51.11 & 65.62 & 85.15 & 965.79 \\
\hline average & 1.92 & 2.00 & 21.11 & 43.09 & 47.14 & 469.82 \\
\hline \multicolumn{7}{|c|}{ MCO 3} \\
\hline & $\mathbf{P M}_{10}$ & $\mathbf{P M}_{2.5}$ & $\mathrm{SO}_{2}$ & $\mathrm{NO}_{2}$ & $\mathrm{O}_{3}$ & $\mathrm{CO}$ \\
\hline $\min$ & 0.41 & 0.41 & 15.24 & 29.58 & 34.35 & 221.88 \\
\hline $\max$ & 3.73 & 3.73 & 24.98 & 44.80 & 52.52 & 497.32 \\
\hline average & 1.51 & 1.51 & 18.89 & 37.17 & 42.99 & 325.82 \\
\hline
\end{tabular}

Table 6. Percentage increase and decrease of pollutants during different phases of MCO over KJ (note: - reduction and + increase).

\begin{tabular}{|c|c|c|c|c|c|c|c|}
\hline \multicolumn{2}{|c|}{ МСО-СМСО } & \multicolumn{2}{|c|}{ CMCO-RMCO } & \multicolumn{2}{|c|}{ RMCO-MCO 2} & \multicolumn{2}{|c|}{ MCO 2-MCO 3} \\
\hline \multicolumn{2}{|c|}{ Percentage \% } & \multicolumn{2}{|c|}{ Percentage \% } & \multicolumn{2}{|c|}{ Percentage $\%$} & \multicolumn{2}{|c|}{ Percentage \% } \\
\hline $\mathbf{P M}_{10}$ & -0.58 & $\mathbf{P M}_{10}$ & -78.47 & $\mathbf{P M}_{10}$ & +50.76 & $\mathbf{P M}_{10}$ & -27.40 \\
\hline $\mathbf{P M}_{2.5}$ & -13.81 & $\mathbf{P M}_{2.5}$ & -64.19 & $\mathbf{P M}_{2.5}$ & +53.74 & $\mathbf{P M}_{2.5}$ & -20.12 \\
\hline $\mathrm{SO}_{2}$ & -5.23 & $\mathrm{SO}_{2}$ & -30.36 & $\mathrm{SO}_{2}$ & +49.56 & $\mathrm{SO}_{2}$ & -11.75 \\
\hline $\mathrm{NO}_{2}$ & +0.79 & $\mathrm{NO}_{2}$ & -9.01 & $\mathrm{NO}_{2}$ & +6.41 & $\mathrm{NO}_{2}$ & -15.93 \\
\hline $\mathrm{O}_{3}$ & -15.63 & $\mathrm{O}_{3}$ & +29.51 & $\mathrm{O}_{3}$ & +5.43 & $\mathrm{O}_{3}$ & -9.66 \\
\hline $\mathrm{CO}$ & +65.74 & $\mathrm{CO}$ & +7.91 & $\mathrm{CO}$ & -2.34 & $\mathrm{CO}$ & -44.19 \\
\hline
\end{tabular}




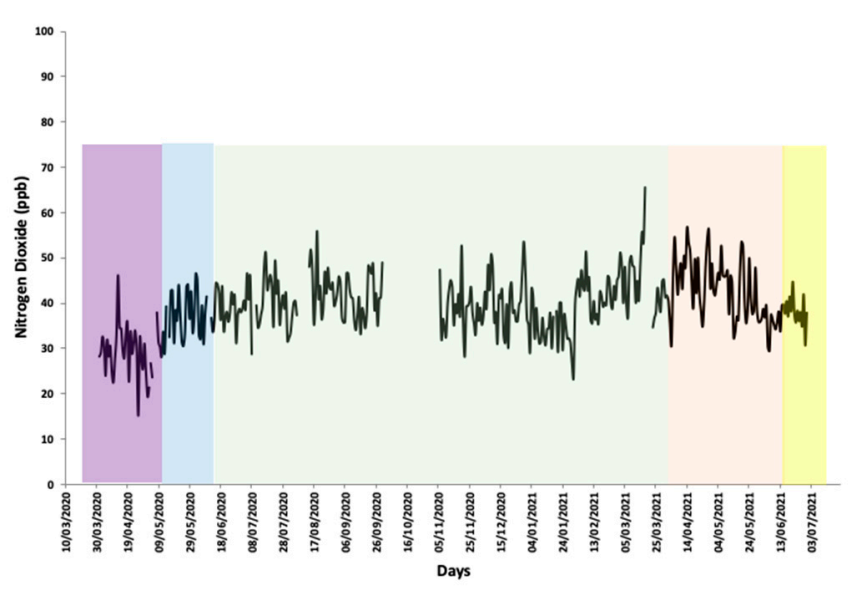

(a)

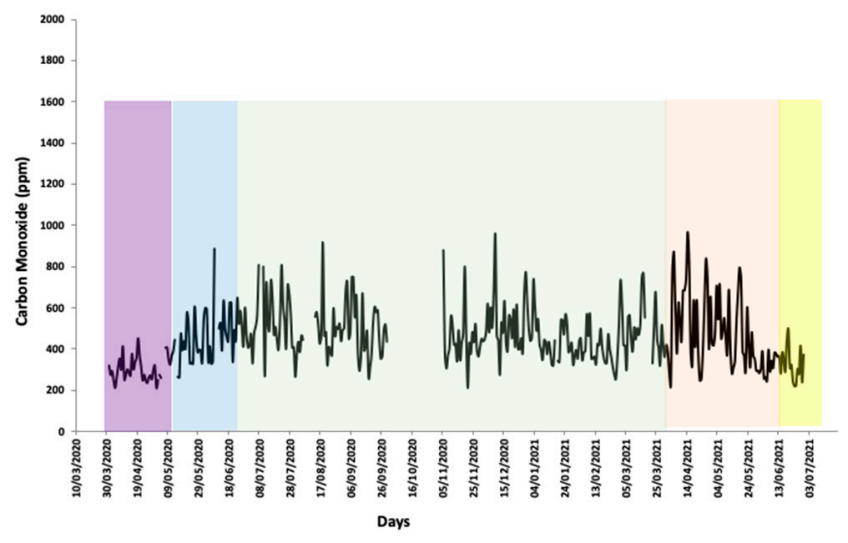

(c)

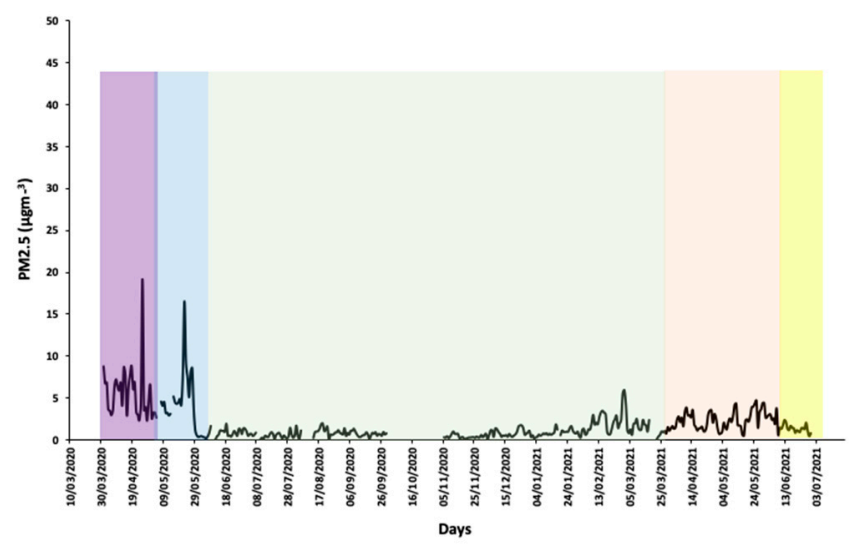

(e)

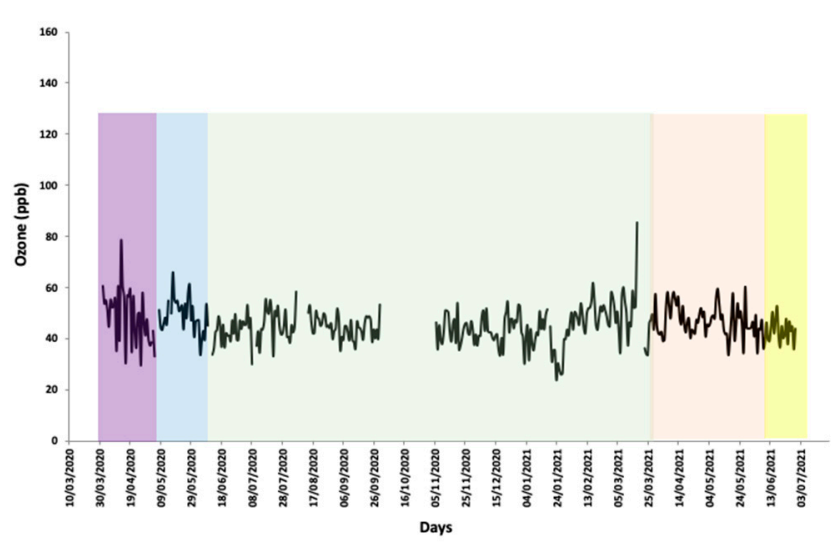

(b)

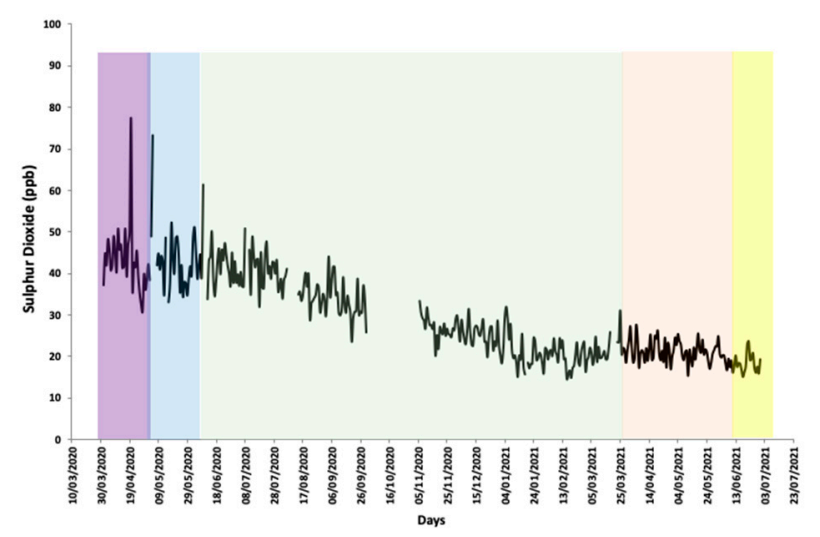

(d)

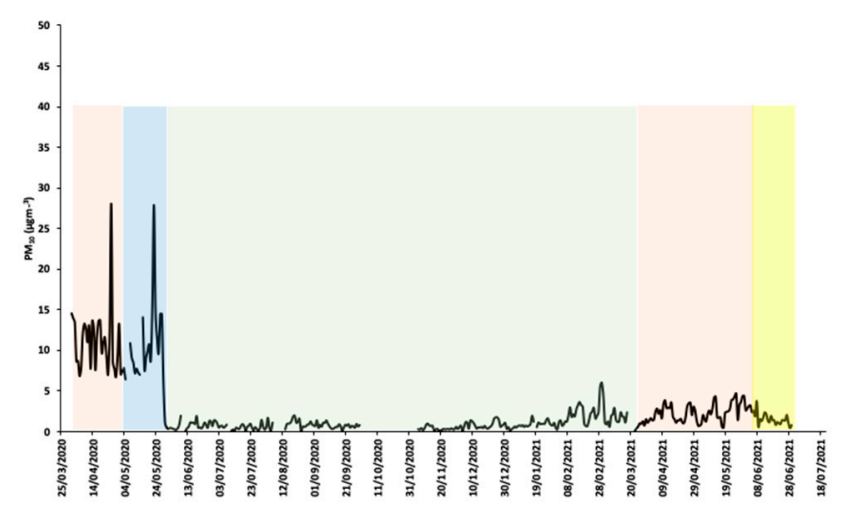

(f)

Figure 4. (a-f) Daily concentration of (a) $\mathrm{NO}_{2}$, (b) $\mathrm{CO}$, (c) $\mathrm{O}_{3}$, (d) $\mathrm{SO}_{2}$, (e) $\mathrm{PM}_{2.5}$ and (f) $\mathrm{PM}_{10}$ during normal days, MCO 1, $\mathrm{CMCO}, \mathrm{RMCO}, \mathrm{MCO} 2$ and MCO 3 over KJ. (Note: color bands represent different phases, white (normal), purple (MCO 1), blue (CMCO), green (RMCO), orange (MCO 2) and yellow (MCO 3). 

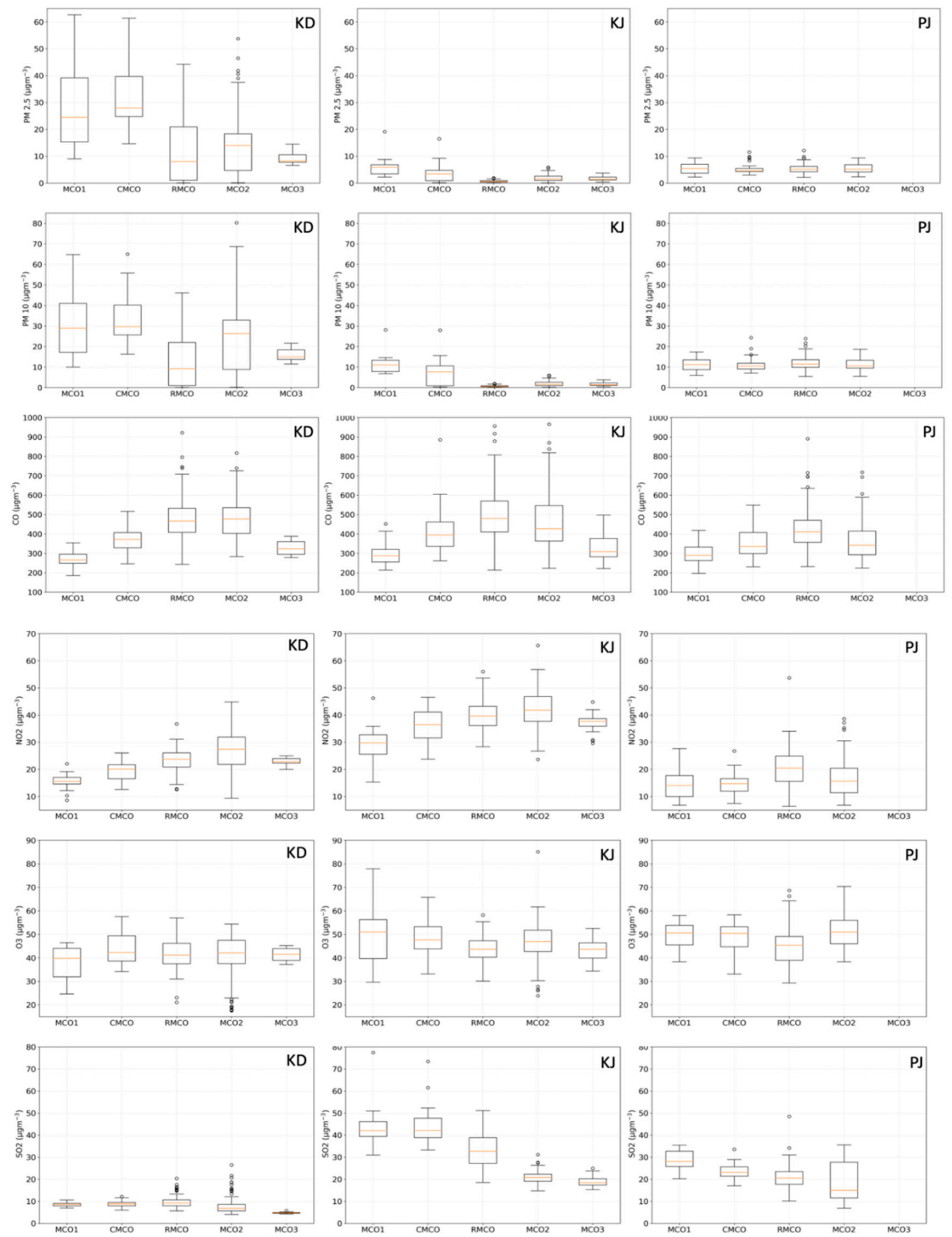

Figure 5. Boxplot of all measured air pollutants at the three stations.

\subsubsection{Kota Damansara}

Table 7 and Figure 6 show the average daily concentration data and time series of measured air pollutants over the KD area. The daily average $\mathrm{PM}_{10}$ and $\mathrm{PM}_{2.5}$ during normal days were $21.68 \mathrm{\mu gm}^{-3}$ and $10.4 \mathrm{\mu gm}^{-3}$, respectively. The highest maximum concentration was recorded for $\mathrm{CO}$ with a maximum of $1191.08 \mathrm{ppb}$. The $\mathrm{O}_{3}, \mathrm{NO}_{2}$ and $\mathrm{SO}_{2}$ daily averages were $53.51 \mathrm{ppb}, 18.11 \mathrm{ppb}$ and $42.37 \mathrm{ppb}$, respectively. Nevertheless, all pollutant concentrations were still below MAAQS values, except for $\mathrm{SO}_{2}$ and $\mathrm{NO}_{2}$, which were high during RMCO with daily averages of $48.49 \mathrm{ppb}$ and $53.69 \mathrm{ppb}$, respectively 
(MAAQS daily averages were $30.5 \mathrm{ppb}$ and $42.5 \mathrm{ppb}$ for $\mathrm{SO}_{2}$ and $\mathrm{NO}_{2}$, respectively, as shown in Table 3).

Table 7. Daily concentrations of $\mathrm{PM}_{10}, \mathrm{PM}_{2.5}, \mathrm{SO}_{2}, \mathrm{NO}_{2}, \mathrm{O}_{3}$ and $\mathrm{CO}$ over $\mathrm{KD}$ (note: unit for PM is in $\mathrm{\mu gm}^{-3} ; \mathrm{SO}_{2}, \mathrm{NO}_{2}, \mathrm{O}_{3}$ and $\mathrm{CO}$ are in $\left.\mathrm{ppb}\right)$.

\begin{tabular}{|c|c|c|c|c|c|c|}
\hline \multicolumn{7}{|c|}{ Normal } \\
\hline & $\mathbf{P M}_{10}$ & $\mathrm{PM}_{2.5}$ & $\mathrm{SO}_{2}$ & $\mathrm{NO}_{2}$ & $\mathrm{O}_{3}$ & $\mathrm{CO}$ \\
\hline $\min$ & 10.02 & 3.95 & 20.72 & 6.28 & 16.67 & 245.68 \\
\hline $\max$ & 39.22 & 23.90 & 78.70 & 40.74 & 76.77 & 1191.08 \\
\hline average & 21.68 & 10.40 & 42.37 & 18.11 & 53.51 & 546.74 \\
\hline \multicolumn{7}{|c|}{ MCO } \\
\hline & $\mathbf{P M}_{10}$ & $\mathrm{PM}_{2.5}$ & $\mathrm{SO}_{2}$ & $\mathrm{NO}_{2}$ & $\mathrm{O}_{3}$ & $\mathrm{CO}$ \\
\hline $\min$ & 5.86 & 2.26 & 20.20 & 6.77 & 38.31 & 196.98 \\
\hline $\max$ & 17.36 & 9.36 & 35.39 & 27.60 & 58.06 & 418.13 \\
\hline average & 11.14 & 5.51 & 28.65 & 14.47 & 49.73 & 300.36 \\
\hline \multicolumn{7}{|c|}{ CMCO } \\
\hline & $\mathbf{P M}_{10}$ & $\mathbf{P M}_{2.5}$ & $\mathrm{SO}_{2}$ & $\mathrm{NO}_{2}$ & $\mathrm{O}_{3}$ & $\mathrm{CO}$ \\
\hline $\min$ & 7.09 & 2.97 & 17.02 & 7.40 & 33.05 & 230.61 \\
\hline $\max$ & 24.35 & 11.50 & 33.54 & 26.74 & 58.30 & 549.15 \\
\hline average & 11.44 & 5.48 & 23.32 & 14.81 & 48.03 & 351.71 \\
\hline \multicolumn{7}{|c|}{ RMCO } \\
\hline & $\mathbf{P M}_{10}$ & $\mathrm{PM}_{2.5}$ & $\mathrm{SO}_{2}$ & $\mathrm{NO}_{2}$ & $\mathrm{O}_{3}$ & $\mathrm{CO}$ \\
\hline $\min$ & 5.43 & 2.15 & 6.86 & 6.40 & 29.28 & 227.07 \\
\hline $\max$ & 23.86 & 12.14 & 48.49 & 53.69 & 68.69 & 890.69 \\
\hline average & 11.84 & 5.44 & 19.77 & 18.90 & 46.80 & 411.43 \\
\hline \multicolumn{7}{|c|}{ MCO 2} \\
\hline & $\mathbf{P M}_{10}$ & $\mathrm{PM}_{2.5}$ & $\mathrm{SO}_{2}$ & $\mathrm{NO}_{2}$ & $\mathrm{O}_{3}$ & $\mathrm{CO}$ \\
\hline $\min$ & 3.39 & 0.26 & 4.60 & 12.73 & 17.72 & 283.20 \\
\hline $\max$ & 68.72 & 46.50 & 14.78 & 44.84 & 54.35 & 817.66 \\
\hline average & 29.82 & 16.05 & 7.65 & 29.48 & 42.08 & 505.26 \\
\hline \multicolumn{7}{|c|}{ MCO 3} \\
\hline & $\mathbf{P M}_{10}$ & $\mathbf{P M}_{2.5}$ & $\mathrm{SO}_{2}$ & $\mathrm{NO}_{2}$ & $\mathrm{O}_{3}$ & $\mathrm{CO}$ \\
\hline $\min$ & 9.47 & 6.33 & 4.02 & 15.31 & 23.83 & 278.20 \\
\hline $\max$ & 60.09 & 53.72 & 14.54 & 39.83 & 51.78 & 694.75 \\
\hline average & 26.51 & 17.89 & 6.13 & 27.29 & 42.73 & 453.10 \\
\hline
\end{tabular}

During MCO 1, all pollutant concentrations for the MCO, CMCO and RMCO were significantly lower in comparison to the readings from a normal day as shown in Table 7. Similar observations were also reported in $[9,12]$ due to the decreased numbers of vehicles and industries that were operating during the $\mathrm{MCO}$ in Malaysia. During $\mathrm{CMCO}$, most air pollutant concentrations increased by $0.31 \%, 15.07 \%, 18.09 \%, 23.90 \%$ and $45.67 \%$ for $\mathrm{PM}_{10}$, $\mathrm{SO}_{2}, \mathrm{NO}_{2}, \mathrm{O}_{3}$ and $\mathrm{CO}$, respectively, whereas the concentration of $\mathrm{PM}_{2.5}$ decreased by $2.03 \%$ as shown in Table 8. 


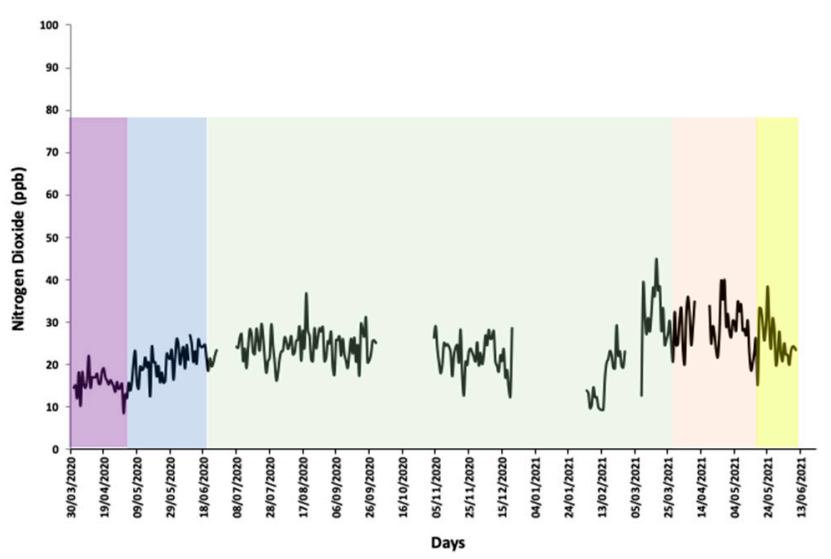

(a)

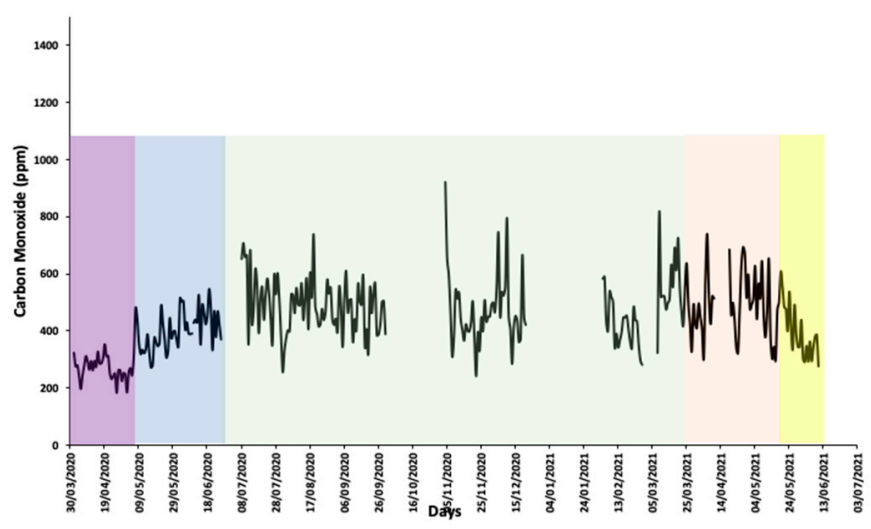

(c)

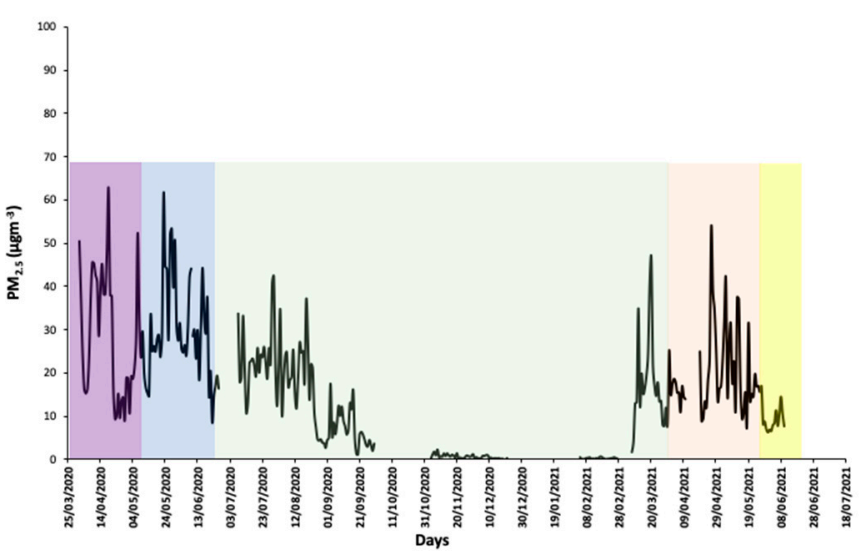

(e)

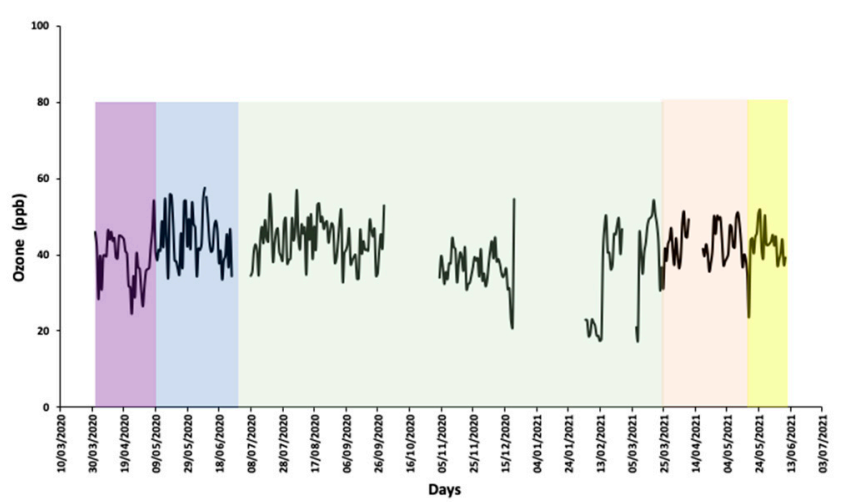

(b)

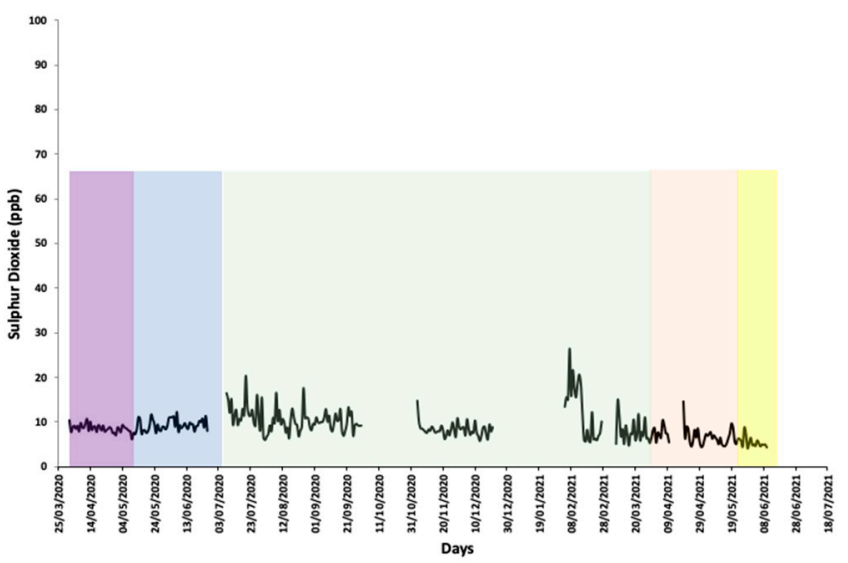

(d)

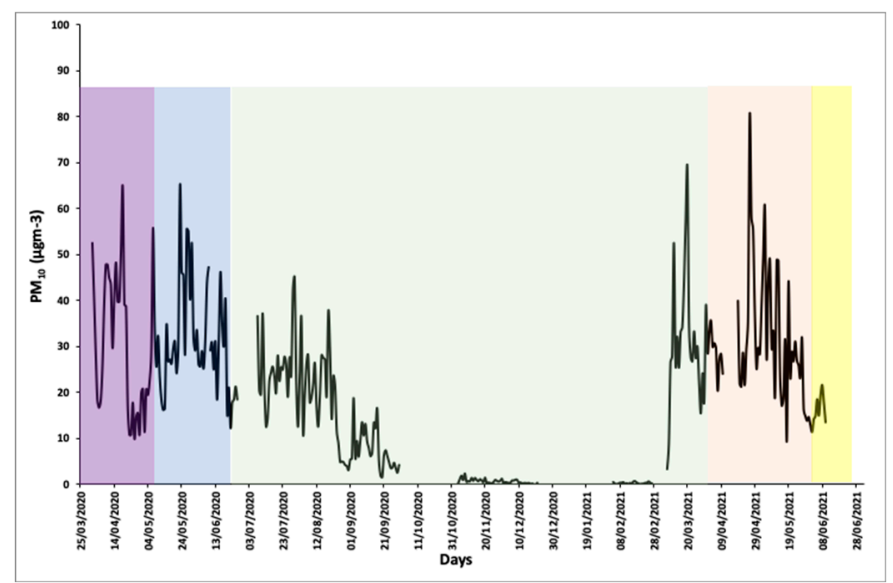

(f)

Figure 6. Daily concentrations of (a) $\mathrm{NO}_{2}$, (b) $\mathrm{CO}$, (c) $\mathrm{O}_{3}$, (d) $\mathrm{SO}_{2}$, (e) $\mathrm{PM}_{2.5}$ and (f) $\mathrm{PM}_{10}$ during normal days, $\mathrm{MCO} 1$, $\mathrm{CMCO}, \mathrm{RMCO}, \mathrm{MCO} 2$ and MCO 3 over Kota Damansara (KD). (Note: color bands represent different phases, white (normal), purple (MCO 1), blue (CMCO), green (RMCO), orange (MCO 2) and yellow (MCO 3).

These observations could be expected from the increased numbers of vehicles and increased industrial activity during this period in the KD area. On the other hand, during RMCO, significant increases were observed for most pollutants, with increases of $23.5 \%$, $54.09 \%, 72.22 \%$ and $78.60 \%$ for $\mathrm{PM}_{10}, \mathrm{SO}_{2}, \mathrm{NO}_{2}$ and $\mathrm{CO}$, respectively, while small decreases of $12.46 \%$ and $0.99 \%$ were recorded for $\mathrm{PM}_{2.5}$ and $\mathrm{O}_{3}$, respectively. During $\mathrm{RMCO}$, the relaxed restrictions and increase in activities allowed by the government led to the increase in most of the pollutants. Finally, Figure 5 show overall average concentrations of all 
measured pollutants during different phases of lockdown at all sensor locations in the Klang Valley.

Table 8. Percentage increase and decrease in pollutants during normal days to MCO, MCO to RMCO and RMCO to CMCO over KD (note: - reduction and + increase).

\begin{tabular}{cccccccc}
\hline \multicolumn{2}{c}{ MCO-CMCO } & \multicolumn{2}{c}{ CMCO-RMCO } & \multicolumn{2}{c}{ RMCO-MCO 2 } & \multicolumn{2}{c}{ MCO 2-MCO 3 } \\
\hline \multicolumn{2}{c}{ Percentage \% } & \multicolumn{2}{c}{ Percentage \% } & \multicolumn{2}{c}{ Percentage \% } & \multicolumn{2}{c}{ Percentage \% } \\
\hline $\mathrm{PM}_{10}$ & +0.31 & $\mathrm{PM}_{10}$ & +23.50 & $\mathrm{PM}_{10}$ & +42.42 & $\mathrm{PM}_{10}$ & +11.12 \\
\hline $\mathrm{PM}_{2.5}$ & -2.03 & $\mathrm{PM}_{2.5}$ & -12.46 & $\mathrm{M}_{2.5}$ & +20.52 & $\mathrm{PM}_{2.5}$ & +10.25 \\
\hline $\mathrm{SO}_{2}$ & +15.07 & $\mathrm{SO}_{2}$ & +54.09 & $\mathrm{SO}_{2}$ & -15.40 & $\mathrm{SO}_{2}$ & -19.81 \\
\hline $\mathrm{NO}_{2}$ & +18.09 & $\mathrm{NO}_{2}$ & +72.22 & $\mathrm{NO}_{2}$ & +16.66 & $\mathrm{NO}_{2}$ & +7.44 \\
\hline $\mathrm{O}_{3}$ & +23.90 & $\mathrm{O}_{3}$ & -0.99 & $\mathrm{O}_{3}$ & +2.57 & $\mathrm{O}_{3}$ & +1.52 \\
\hline $\mathrm{CO}$ & +45.67 & $\mathrm{CO}$ & +78.60 & $\mathrm{CO}$ & -5.00 & $\mathrm{CO}$ & -11.51 \\
\hline
\end{tabular}

\subsection{Statistical Analysis}

Air Pollutant Correlations

In this section, the Spearman correlation test was chosen to investigate the correlations between each pollutant at all stations from the MCO to MCO 3 periods as shown in Table 9. Strong correlations between $\mathrm{PM}_{2.5}$ and $\mathrm{PM}_{10}$ were observed at all stations with $\mathrm{r}^{2}$ of 0.9 $(p<0.01)$ suggesting that both were emitted from the same sources, mainly from vehicular and industrial emissions. Positive correlations $\left(0.13<\mathrm{r}^{2}<0.48, p<0.01\right)$ were obtained between $\mathrm{NO}_{2}$ and $\mathrm{O}_{3}$ at all stations. The relationship between $\mathrm{O}_{3}$ and $\mathrm{NO}_{2}$ has been investigated in many previous studies (e.g., [1,21]). Atmospheric $\mathrm{O}_{3}$ levels are determined by emissions of $\mathrm{O}_{3}$ precursors (such as volatile organic compounds (VOCs), $\mathrm{NO}_{2}$ and $\mathrm{CO}$ ), atmospheric nitrogen oxide $\left(\mathrm{NO}_{\mathrm{x}}\right)$ photochemistry and transport $[22,23]$.

Table 9. Analysis of the relationships between individual air pollutants at all stations based on Pearson's correlation coefficients $\left(\mathrm{r}^{2}, p<0.01\right)$.

\begin{tabular}{|c|c|c|c|c|c|c|}
\hline \multirow{2}{*}{ Pollutants } & \multicolumn{6}{|c|}{ PJ } \\
\hline & $\mathrm{NO}_{2}$ & $\mathrm{O}_{3}$ & $\mathrm{SO}_{2}$ & $\mathrm{CO}$ & $\mathbf{P M}_{2.5}$ & $\mathrm{PM}_{10}$ \\
\hline $\mathrm{NO}_{2}$ & 1 & 0.13 & 0.0004 & 0.23 & 0.031 & 0.023 \\
\hline $\mathrm{O}_{3}$ & 0.13 & 1 & 0.03 & 0.14 & 0.32 & 0.20 \\
\hline $\mathrm{SO}_{2}$ & 0.0004 & 0.03 & 1 & 0.23 & 0.33 & 0.40 \\
\hline $\mathrm{CO}$ & 0.23 & 0.14 & 0.23 & 1 & 0.33 & 0.32 \\
\hline $\mathrm{PM}_{2.5}$ & 0.031 & 0.32 & 0.33 & 0.33 & 1 & 0.91 \\
\hline \multirow[t]{3}{*}{$\mathrm{PM}_{10}$} & 0.023 & 0.20 & 0.40 & 0.32 & 0.91 & 1 \\
\hline & \multicolumn{6}{|c|}{ KJ } \\
\hline & $\mathrm{NO}_{2}$ & $\mathrm{O}_{3}$ & $\mathrm{SO}_{2}$ & $\mathrm{CO}$ & $\mathbf{P M}_{2.5}$ & $\mathbf{P M}_{10}$ \\
\hline $\mathrm{NO}_{2}$ & 1 & 0.48 & 0.0012 & 0.002 & 0.12 & 0.17 \\
\hline $\mathrm{O}_{3}$ & 0.48 & 1 & 0.020 & 0.25 & 0.006 & 0.0012 \\
\hline $\mathrm{SO}_{2}$ & 0.0012 & 0.020 & 1 & 0.25 & 0.007 & 0.019 \\
\hline $\mathrm{CO}$ & 0.42 & 0.25 & 0.25 & 1 & 0.002 & 0.0017 \\
\hline $\mathrm{PM}_{2.5}$ & 0.12 & 0.006 & 0.007 & 0.002 & 1 & 0.92 \\
\hline $\mathrm{PM}_{10}$ & 0.17 & 0.0012 & 0.019 & 0.0017 & 0.92 & 1 \\
\hline
\end{tabular}


Table 9. Cont.

\begin{tabular}{ccccccc}
\hline & \multicolumn{7}{c}{ KD } \\
\cline { 2 - 7 } & $\mathbf{N O}_{\mathbf{2}}$ & $\mathbf{O}_{\mathbf{3}}$ & $\mathbf{S O}_{\mathbf{2}}$ & $\mathbf{C O}$ & $\mathbf{P M}_{\mathbf{2 . 5}}$ & $\mathbf{P M}_{\mathbf{1 0}}$ \\
\hline $\mathrm{NO}_{2}$ & 1 & 0.36 & 0.045 & 0.41 & 0.010 & 0.084 \\
\hline $\mathrm{O}_{3}$ & 0.36 & 1 & 0.061 & 0.020 & 0.010 & 0.18 \\
\hline $\mathrm{SO}_{2}$ & 0.045 & 0.061 & 1 & 0.068 & 0.0002 & 0.015 \\
\hline $\mathrm{CO}$ & 0.41 & 0.020 & 0.068 & 1 & 0.0007 & 0.005 \\
\hline $\mathrm{PM}_{2.5}$ & 0.010 & 0.010 & 0.0002 & 0.0007 & 1 & 0.90 \\
\hline $\mathrm{PM}_{10}$ & 0.084 & 0.18 & 0.015 & 0.005 & 0.90 & 1 \\
\hline
\end{tabular}

Positive correlations between $\mathrm{CO}$ and $\mathrm{NO}_{2}$ at $\mathrm{PJ}, \mathrm{KJ}$ and $\mathrm{KD}$ were observed with $\mathrm{r}^{2}(p<0.01)$ values of $0.23,0.42$ and 0.41 , respectively. The positive correlation may be supported by the reaction of $\mathrm{CO}$ entering the cycle of oxidation and nitrogen monoxide (NO) being oxidized to $\mathrm{NO}_{2}$ [24].

\subsection{Effect of Meteorological Factors on the Air Pollutants}

Table 10 shows the statistical Spearman analysis between air pollutants and meteorological factors (temperature and $\mathrm{RH}$ ) at all stations. Of these meteorological factors, only $\mathrm{KJ}$ had positive correlations between $\mathrm{SO}_{2}$ and temperature and $\mathrm{RH}$ with $\mathrm{r}^{2}$ values 0.67 and 0.54 , respectively. All air pollutants had weak correlations with temperature and $\mathrm{RH}$ at most of the stations, suggesting that the contributions of vehicular and industrial sources were not influenced by the temperature and $\mathrm{RH}$. This finding is similar to that found by [25] over an urban area of Chengdu, China. They suggested that it may be related to the different physical characteristics, sources, wind speed, wind direction and compositions of the air pollutants.

Table 10. Pearson's correlation coefficients $\left(\mathrm{r}^{2}\right)$ for air pollutants and meteorological factors (temperature and $\mathrm{RH}$ ) at all stations.

\section{PJS}

\begin{tabular}{ccc}
\hline Air Pollutants & Temp $\left({ }^{\circ} \mathbf{C}\right)$ & Relative Humidity (\%) \\
\hline $\mathrm{NO}_{2}$ & 0.03 & -0.081 \\
\hline $\mathrm{O}_{3}$ & 0.08 & -0.003 \\
\hline $\mathrm{SO}_{2}$ & -0.03 & -0.010 \\
\hline $\mathrm{CO}$ & 0.02 & 0.11 \\
\hline $\mathrm{PM}_{2.5}$ & -0.01 & -0.006 \\
\hline $\mathrm{PM}_{10}$ & -0.01 & -0.006 \\
\hline & & \\
\hline Air Pollutants & Temp $\left({ }^{\circ} \mathbf{C}\right)$ & Relative Humidity (\%) \\
\hline $\mathrm{NO}_{2}$ & -0.003 & -0.0014 \\
\hline $\mathrm{O}_{3}$ & -0.04 & -0.0462 \\
\hline $\mathrm{SO}_{2}$ & 0.67 & 0.538 \\
\hline $\mathrm{CO}$ & 0.1214 & 0.1435 \\
\hline $\mathrm{PM}_{2.5}$ & -0.0111 & -0.0168 \\
\hline $\mathrm{PM}_{10}$ & -0.0446 & -0.0589 \\
\hline & &
\end{tabular}


Table 10. Cont.

\begin{tabular}{ccc}
\hline & \multicolumn{2}{c}{ KD } \\
\hline Air Pollutants & Temp $\left({ }^{\circ} \mathbf{C}\right)$ & Relative Humidity (\%) \\
\hline $\mathrm{NO}_{2}$ & -0.027 & -0.027 \\
\hline $\mathrm{O}_{3}$ & -0.044 & -0.006 \\
\hline $\mathrm{SO}_{2}$ & -0.015 & -0.039 \\
\hline $\mathrm{CO}$ & -0.077 & -0.029 \\
\hline $\mathrm{PM}_{2.5}$ & -0.007 & -0.030 \\
\hline $\mathrm{PM}_{10}$ & -0.047 & -0.047 \\
\hline
\end{tabular}

3.5. Non-Carcinogenic Risk of $\mathrm{NO}_{2}, \mathrm{SO}_{2}, \mathrm{CO}, \mathrm{O}_{3}, \mathrm{PM}_{10}$ and $\mathrm{PM}_{2.5}$

The non-carcinogenic risks due to exposure to $\mathrm{NO}_{2}, \mathrm{SO}_{2}, \mathrm{CO}, \mathrm{O}_{3}, \mathrm{PM}_{10}$ and $\mathrm{PM}_{2.5}$ via the inhalation route at all three locations are shown in Tables 11-13. All exposure factor parameters for health risk assessment calculated in this study is stated in Table 14. Inhalation was considered as the major route for exposure to the air contaminants. The calculated health quotients (HQ) for $\mathrm{NO}_{2}, \mathrm{PM}_{10}$ and $\mathrm{PM}_{2.5}$ across the exposed groups at all locations and different $\mathrm{MCO}$ were less than $1(\mathrm{HQ}<1)$. These findings indicated that the concentration levels for $\mathrm{NO}_{2}, \mathrm{O}_{3}, \mathrm{PM}_{10}$ and $\mathrm{PM}_{2.5}$ observed for $\mathrm{KD}, \mathrm{KJ}$ and $\mathrm{PJ}$ during the period were unlikely to cause non-carcinogenic effects. However, the $\mathrm{HQ}$ of exposure to $\mathrm{SO}_{2}$ in $\mathrm{KJ}$ during MCO, CMCO and RMCO among infants ( $0-1$ years) and children ( $2-5$ years) was greater than $1(\mathrm{HQ}>1)$.

Table 11. Hazard quotients and cancer risk for ambient air pollutants in KD.

\begin{tabular}{|c|c|c|c|c|c|c|c|}
\hline & & \multicolumn{6}{|c|}{ MCO } \\
\hline & & $\mathbf{P M}_{10}$ & $\mathbf{P M}_{2.5}$ & $\mathrm{SO}_{2}$ & $\mathrm{NO}_{2}$ & $\mathrm{O}_{3}$ & $\mathrm{CO}$ \\
\hline \multirow[t]{2}{*}{ Infant (0-1 year) } & HQ & $2.36 \times 10^{-1}$ & $6.33 \times 10^{-1}$ & $2.19 \times 10^{-1}$ & $3.25 \times 10^{-1}$ & $5.96 \times 10^{-1}$ & $2.42 \times 10^{+1}$ \\
\hline & CR & & $2.53 \times 10^{-3}$ & & & & \\
\hline \multirow[t]{2}{*}{ Child (2-5 years) } & HQ & $2.14 \times 10^{-1}$ & $5.76 \times 10^{-1}$ & $1.99 \times 10^{-1}$ & $2.96 \times 10^{-1}$ & $5.42 \times 10^{-1}$ & $2.20 \times 10^{+1}$ \\
\hline & CR & & $1.38 \times 10^{+2}$ & & & & \\
\hline \multirow[t]{2}{*}{ Child (6-12 years) } & HQ & $1.34 \times 10^{-1}$ & $3.61 \times 10^{-1}$ & $1.25 \times 10^{-1}$ & $1.85 \times 10^{-1}$ & $3.40 \times 10^{-1}$ & $1.38 \times 10^{+1}$ \\
\hline & $\mathrm{CR}$ & & $1.73 \times 10^{-2}$ & & & & \\
\hline \multirow[t]{3}{*}{ Adult (19-75 years) } & HQ & $8.63 \times 10^{-2}$ & $2.32 \times 10^{-1}$ & $8.02 \times 10^{-2}$ & $1.19 \times 10^{-1}$ & $2.18 \times 10^{-1}$ & $8.84 \times 10$ \\
\hline & $\mathrm{CR}$ & & $2.78 \times 10^{-2}$ & & & & \\
\hline & & & & & & & \\
\hline \multirow[t]{2}{*}{ Infant (0-1 years) } & HQ & $2.60 \times 10^{-1}$ & $7.05 \times 10^{-1}$ & $2.28 \times 10^{-1}$ & $2.64 \times 10^{-1}$ & $6.98 \times 10^{-1}$ & $2.20 \times 10^{+1}$ \\
\hline & CR & & $2.82 \times 10^{-3}$ & & & & \\
\hline \multirow[t]{2}{*}{ Child ( $2-5$ years) } & HQ & $2.37 \times 10^{-1}$ & $6.42 \times 10^{-1}$ & $2.07 \times 10^{-1}$ & $2.40 \times 10^{-1}$ & $6.35 \times 10^{-1}$ & $2.01 \times 10^{+1}$ \\
\hline & CR & & $1.54 \times 10^{-2}$ & & & & \\
\hline \multirow[t]{2}{*}{ Child (6-12 years) } & HQ & $1.48 \times 10^{-1}$ & $4.02 \times 10^{-1}$ & $1.30 \times 10^{-1}$ & $1.50 \times 10^{-1}$ & $3.98 \times 10^{-1}$ & $1.26 \times 10^{+1}$ \\
\hline & $\mathrm{CR}$ & & $1.93 \times 10^{-2}$ & & & & \\
\hline \multirow[t]{2}{*}{ Adult (19-75 years) } & HQ & $9.53 \times 10^{-2}$ & $2.58 \times 10^{-1}$ & $8.35 \times 10^{-2}$ & $9.66 \times 10^{-2}$ & $2.56 \times 10^{-1}$ & $8.07 \times 10$ \\
\hline & CR & & $3.10 \times 10^{-2}$ & & & & \\
\hline
\end{tabular}


Table 11. Cont.

\begin{tabular}{|c|c|c|c|c|c|c|c|}
\hline \multirow[b]{2}{*}{ Infant ( $0-1$ year $)$} & \multirow[b]{2}{*}{ HQ } & \multicolumn{6}{|c|}{ RMCO } \\
\hline & & $1.34 \times 10^{-1}$ & $2.85 \times 10^{-1}$ & $2.31 \times 10^{-1}$ & $5.15 \times 10^{-1}$ & $6.40 \times 10^{-1}$ & $4.29 \times 10^{+1}$ \\
\hline & CR & & $1.14 \times 10^{-3}$ & & & & \\
\hline \multirow[t]{2}{*}{ Child ( $2-5$ years) } & HQ & $1.22 \times 10^{-1}$ & $2.59 \times 10^{-1}$ & $2.10 \times 10^{-1}$ & $4.69 \times 10^{-1}$ & $5.82 \times 10^{-1}$ & $3.90 \times 10^{+1}$ \\
\hline & CR & & $6.21 \times 10^{-3}$ & & & & \\
\hline \multirow[t]{2}{*}{ Child (6-12 years) } & HQ & $7.64 \times 10^{-2}$ & $1.62 \times 10^{-1}$ & $1.32 \times 10^{-1}$ & $2.94 \times 10^{-1}$ & $3.65 \times 10^{-1}$ & $2.45 \times 10^{+1}$ \\
\hline & CR & & $7.79 \times 10^{-3}$ & & & & \\
\hline \multirow[t]{2}{*}{ Adult (19-75 years) } & HQ & $4.91 \times 10^{-2}$ & $1.04 \times 10^{-1}$ & $8.46 \times 10^{-2}$ & $1.89 \times 10^{-1}$ & $2.34 \times 10^{-1}$ & $1.57 \times 10^{+1}$ \\
\hline & CR & & $1.25 \times 10^{-2}$ & & & & \\
\hline
\end{tabular}

Table 12. Hazard quotients and cancer risk for ambient air pollutants in KJ.

\begin{tabular}{|c|c|c|c|c|c|c|c|}
\hline & & \multicolumn{6}{|c|}{ MCO } \\
\hline & & $\mathbf{P M}_{10}$ & $\mathbf{P M}_{2.5}$ & $\mathrm{SO}_{2}$ & $\mathrm{NO}_{2}$ & $\mathrm{O}_{3}$ & $\mathrm{CO}$ \\
\hline \multirow[t]{2}{*}{ Infant ( $0-1$ year) } & HQ & $8.64 \times 10^{-2}$ & $1.25 \times 10^{-1}$ & $1.11 \times 10$ & $6.13 \times 10^{-1}$ & $7.67 \times 10^{-1}$ & $2.66 \times 10^{+1}$ \\
\hline & CR & & $5.01 \times 10^{-4}$ & & & & \\
\hline \multirow[t]{2}{*}{ Child ( $2-5$ years) } & HQ & $7.86 \times 10^{-2}$ & $1.14 \times 10^{-1}$ & $1.01 \times 10$ & $5.58 \times 10^{-1}$ & $6.98 \times 10^{-1}$ & $2.42 \times 10^{+1}$ \\
\hline & $\mathrm{CR}$ & & $2.74 \times 10^{-3}$ & & & & \\
\hline \multirow[t]{2}{*}{ Child (6-12 years) } & HQ & $4.93 \times 10^{-2}$ & $7.14 \times 10^{-2}$ & $6.31 \times 10^{-1}$ & $3.49 \times 10^{-1}$ & $4.37 \times 10^{-1}$ & $\mathbf{1 . 5 1} \times 10^{+1}$ \\
\hline & CR & & $3.43 \times 10^{-3}$ & & & & \\
\hline \multirow[t]{3}{*}{ Adult (19-75 years) } & HQ & $3.16 \times 10^{-2}$ & $4.59 \times 10^{-2}$ & $4.05 \times 10^{-1}$ & $2.24 \times 10^{-1}$ & $2.81 \times 10^{-1}$ & $9.73 \times 10$ \\
\hline & $\mathrm{CR}$ & & $5.51 \times 10^{-3}$ & & & & \\
\hline & & & & & & & \\
\hline \multirow[t]{2}{*}{ Infant ( $0-1$ years) } & HQ & $5.81 \times 10^{-2}$ & $8.59 \times 10^{-2}$ & $1.12 \times 10$ & $7.57 \times 10^{-1}$ & $7.55 \times 10^{-1}$ & $3.74 \times 10^{+1}$ \\
\hline & CR & & $3.44 \times 10^{-4}$ & & & & \\
\hline \multirow[t]{2}{*}{ Child ( $2-5$ years) } & HQ & $5.28 \times 10^{-2}$ & $7.81 \times 10^{-2}$ & $1.02 \times 10$ & $6.89 \times 10^{-1}$ & $6.87 \times 10^{-1}$ & $3.40 \times 10^{+1}$ \\
\hline & $\mathrm{CR}$ & & $1.88 \times 10^{-3}$ & & & & \\
\hline \multirow[t]{2}{*}{ Child (6-12 years) } & HQ & $3.31 \times 10^{-2}$ & $4.89 \times 10^{-2}$ & $6.37 \times 10$ & $4.31 \times 10^{-1}$ & $4.30 \times 10^{-1}$ & $2.13 \times 10^{+1}$ \\
\hline & $\mathrm{CR}$ & & $2.35 \times 10^{-3}$ & & & & \\
\hline \multirow[t]{3}{*}{ Adult (19-75 years) } & HQ & $2.13 \times 10^{-2}$ & $3.14 \times 10^{-2}$ & $4.09 \times 10$ & $2.77 \times 10^{-1}$ & $2.76 \times 10^{-1}$ & $1.37 \times 10^{+1}$ \\
\hline & CR & & $3.77 \times 10^{-3}$ & & & & \\
\hline & & & & & & & \\
\hline \multirow[t]{2}{*}{ Infant ( $0-1$ year) } & HQ & $7.42 \times 10^{-3}$ & $2.07 \times 10^{-2}$ & $1.07 \times 10$ & $8.46 \times 10^{-1}$ & $6.96 \times 10^{-1}$ & $4.30 \times 10^{-1}$ \\
\hline & CR & & $8.30 \times 10^{-5}$ & & & & \\
\hline \multirow[t]{2}{*}{ Child ( $2-5$ years) } & HQ & $6.75 \times 10^{-3}$ & $1.89 \times 10^{-2}$ & $9.73 \times 10^{-1}$ & $7.69 \times 10^{-1}$ & $6.33 \times 10^{-1}$ & $3.91 \times 10^{-1}$ \\
\hline & $\mathrm{CR}$ & & $4.53 \times 10^{-4}$ & & & & \\
\hline \multirow[t]{2}{*}{ Child (6-12 years) } & HQ & $4.23 \times 10^{-3}$ & $1.18 \times 10^{-2}$ & $6.10 \times 10^{-1}$ & $4.82 \times 10^{-1}$ & $3.97 \times 10^{-1}$ & $2.45 \times 10^{-1}$ \\
\hline & $\mathrm{CR}$ & & $5.67 \times 10^{-4}$ & & & & \\
\hline \multirow[t]{2}{*}{ Adult (19-75 years) } & $\mathrm{HQ}$ & $2.72 \times 10^{-3}$ & $7.59 \times 10^{-3}$ & $3.92 \times 10^{-1}$ & $3.10 \times 10^{-1}$ & $2.55 \times 10^{-1}$ & $1.57 \times 10^{-1}$ \\
\hline & $\mathrm{CR}$ & & $9.11 \times 10^{-4}$ & & & & \\
\hline
\end{tabular}


Table 13. Hazard quotients and cancer risk for ambient air pollutants in PJ.

\begin{tabular}{|c|c|c|c|c|c|c|c|}
\hline & & \multicolumn{6}{|c|}{ MCO } \\
\hline & & $\mathbf{P M}_{10}$ & $\mathrm{PM}_{2.5}$ & $\mathrm{SO}_{2}$ & $\mathrm{NO}_{2}$ & $\mathrm{O}_{3}$ & $\mathrm{CO}$ \\
\hline \multirow[t]{2}{*}{ Infant (0-1 y) } & HQ & $8.70 \times 10^{-2}$ & $1.23 \times 10^{-1}$ & $7.32 \times 10^{-1}$ & $3.03 \times 10^{-1}$ & $7.77 \times 10^{-1}$ & $2.68 \times 10^{-1}$ \\
\hline & $\mathrm{CR}$ & & $4.92 \times 10^{-4}$ & & & & \\
\hline \multirow[t]{2}{*}{ Child (2-5 years) } & $\mathrm{HQ}$ & $7.91 \times 10^{-2}$ & $1.12 \times 10^{-1}$ & $6.66 \times 10^{-1}$ & $2.76 \times 10^{-1}$ & $7.07 \times 10^{-1}$ & $2.44 \times 10^{-1}$ \\
\hline & $\mathrm{CR}$ & & $2.68 \times 10^{-3}$ & & & & \\
\hline \multirow[t]{2}{*}{ Child (6-12 years) } & HQ & $4.96 \times 10^{-2}$ & $7.00 \times 10^{-2}$ & $4.17 \times 10^{-1}$ & $1.73 \times 10^{-1}$ & $4.43 \times 10^{-1}$ & $1.53 \times 10^{-1}$ \\
\hline & $\mathrm{CR}$ & & $3.36 \times 10^{-3}$ & & & & \\
\hline \multirow[t]{3}{*}{ Adult (19-75 years) } & HQ & $3.18 \times 10^{-2}$ & $4.50 \times 10^{-2}$ & $2.68 \times 10^{-1}$ & $1.11 \times 10^{-1}$ & $2.84 \times 10^{-1}$ & $9.83 \times 10$ \\
\hline & $\mathrm{CR}$ & & $5.40 \times 10^{-3}$ & & & & \\
\hline & & \multicolumn{6}{|c|}{ CMCO } \\
\hline \multirow[t]{2}{*}{ Infant (0-1 year) } & HQ & $8.93 \times 10^{-2}$ & $1.22 \times 10^{-1}$ & $5.96 \times 10^{-1}$ & $3.11 \times 10^{-1}$ & $7.50 \times 10^{-1}$ & $3.14 \times 10^{+1}$ \\
\hline & $\mathrm{CR}$ & & $4.89 \times 10^{-4}$ & & & & \\
\hline \multirow[t]{2}{*}{ Child (2-5 years) } & HQ & $8.13 \times 10^{-2}$ & $1.11 \times 10^{-1}$ & $5.43 \times 10^{-1}$ & $2.83 \times 10^{-1}$ & $6.82 \times 10^{-1}$ & $2.86 \times 10^{+1}$ \\
\hline & $\mathrm{CR}$ & & $2.67 \times 10^{-3}$ & & & & \\
\hline \multirow[t]{2}{*}{ Child (6-12 years) } & HQ & $5.09 \times 10^{-2}$ & $6.97 \times 10^{-2}$ & $3.40 \times 10^{-1}$ & $1.77 \times 10^{-1}$ & $4.27 \times 10^{-1}$ & $\mathbf{1 . 7 9} \times 10^{+1}$ \\
\hline & $\mathrm{CR}$ & & $3.34 \times 10^{-3}$ & & & & \\
\hline \multirow[t]{3}{*}{ Adult (19-75 years) } & HQ & $3.27 \times 10^{-2}$ & $4.47 \times 10^{-2}$ & $2.18 \times 10^{-1}$ & $1.14 \times 10^{-1}$ & $2.75 \times 10^{+1}$ & $\mathbf{1 . 1 5} \times 10^{+1}$ \\
\hline & CR & & $5.37 \times 10^{-3}$ & & & & \\
\hline & & & & & & & \\
\hline \multirow[t]{2}{*}{ Infant ( $0-1$ year) } & HQ & $9.24 \times 10^{-2}$ & $1.21 \times 10^{-1}$ & $5.05 \times 10^{-1}$ & $3.96 \times 10^{-1}$ & $7.31 \times 10^{-1}$ & $3.68 \times 10^{+1}$ \\
\hline & $\mathrm{CR}$ & & $4.85 \times 10^{-4}$ & & & & \\
\hline \multirow[t]{2}{*}{ Child ( $2-5$ years) } & HQ & $8.41 \times 10^{-2}$ & $1.10 \times 10^{-1}$ & $4.60 \times 10^{-1}$ & $3.61 \times 10^{-1}$ & $6.65 \times 10^{-1}$ & $3.35 \times 10^{+1}$ \\
\hline & $\mathrm{CR}$ & & $2.65 \times 10^{-3}$ & & & & \\
\hline \multirow[t]{2}{*}{ Child (6-12 years) } & HQ & $5.27 \times 10^{-2}$ & $6.92 \times 10^{-2}$ & $2.88 \times 10^{-1}$ & $2.26 \times 10^{-1}$ & $4.16 \times 10^{-1}$ & $2.10 \times 10^{+1}$ \\
\hline & $\mathrm{CR}$ & & $3.32 \times 10^{-3}$ & & & & \\
\hline \multirow[t]{2}{*}{ Adult (19-75 years) } & HQ & $3.38 \times 10^{-2}$ & $4.44 \times 10^{-2}$ & $1.85 \times 10^{-1}$ & $1.45 \times 10^{-1}$ & $2.68 \times 10^{-1}$ & $1.35 \times 10^{+1}$ \\
\hline & $\mathrm{CR}$ & & $5.33 \times 10^{-3}$ & & & & \\
\hline
\end{tabular}

Table 14. Exposure factor parameters for health risk assessment calculation.

\begin{tabular}{|c|c|c|c|c|c|}
\hline \multirow[b]{2}{*}{ Parameter } & \multirow[b]{2}{*}{ Definition } & \multicolumn{4}{|c|}{ Value for Age Categories } \\
\hline & & $\begin{array}{c}\text { Infant } \\
(0-1 \text { year })\end{array}$ & $\begin{array}{c}\text { Child } \\
\text { (2-5 years) }\end{array}$ & $\begin{array}{c}\text { Child } \\
\text { (6-12 years) }\end{array}$ & $\begin{array}{c}\text { Adult } \\
\text { (19-75 years) }\end{array}$ \\
\hline $\mathrm{C}$ & $\begin{array}{l}\text { Mean Concentration of } \mathrm{NO}_{2}, \mathrm{SO}_{2}, \mathrm{CO} \\
\mathrm{PM}_{10} \text { and } \mathrm{PM}_{2.5}\left(\mu \mathrm{g} / \mathrm{m}^{3}\right)\end{array}$ & & & & \\
\hline EF & Exposure frequency (days/year) & 350 & 350 & 350 & 350 \\
\hline ED & Exposure duration (years) & 1 & 6 & 12 & 30 \\
\hline AT noncarc & Averaging time (days) $\mathrm{AT}=\mathrm{ED} \times 365$ days & 365 & 2190 & 4380 & 10,950 \\
\hline AT carc & Averaging time $\mathrm{AT}=70 \times 365$ days & 25,550 & 25,550 & 25,550 & 25,550 \\
\hline BW & Body weight $(\mathrm{kg})$ & 11.3 & 22.6 & 45.3 & 71.8 \\
\hline InhR & Inhalation rate $\left(\mathrm{m}^{3} /\right.$ day $)$ & 9.2 & 16.74 & 21.02 & 21.4 \\
\hline
\end{tabular}


This suggests that infants ( $0-1$ years) and children (2-5 years) have higher potentials to suffer non-cancerous effects due to exposure to $\mathrm{SO}_{2}$. These findings showed that infants ( $0-1$ years) and children (2-5 years) are the part of the population that may be at risk of developing health related issues due to $\mathrm{SO}_{2}$ exposure. Health risks are especially high for children because of their low tolerance to toxins [26,27]. Children have been shown to be more sensitive to environmental pollution than adults. They are considered a risk group due to many reasons, including the relatively higher quantity of air they inhale. A resting infant's air intake per unit weight is double that of an adult, and his or her immune system and lungs are not fully developed.

$\mathrm{KD}, \mathrm{KJ}$ and PJ presented the highest $\mathrm{HQ}$ values for $\mathrm{CO}$ through the inhalation pathway across the different MCOs and exposed populations. Thus, the exposed groups at all study locations faced great potential for incurring non-cancerous effects of CO. The high HQ values indicates that the exposure to the ambient $\mathrm{CO}$ cannot be disregarded, and it's the health implications need further thorough investigation. An investigation by Iqbal and co-workers [28] suggested that CO is often not recognized, and its toxicity is generally underestimated and misdiagnosed owing to its non-irritating character.

\subsection{Carcinogenic Risk of $P M_{2.5}$}

The cancer risk was only calculated for $\mathrm{PM}_{2.5}$ due to the lack of availability of the inhalation unit risk (IUR) values for the other pollutants. Overall, the trend of cancer risk values was similar at all the study locations, across exposed groups and different types of movement control order. All sampling locations and exposed groups recorded a cancer risk $(C R)$ value higher than the acceptable value at $1 \times 10^{-6}$. This indicates that $\mathrm{PM}_{2.5}$ is a contaminant that poses a risk to the exposed population at all study locations.

Thus, it is clear that exposure of populations to the fine particles should be of special concern. On top of that, this indicates that all the exposed population are at a higher risk of developing cancer in the near future owing to the inhalation of $\mathrm{PM}_{2.5}$. We found that the risk of developing cancer was higher among adults compared to children and infants. In this study, the exposure duration and averaging time were set equal to 30 years and 70 years respectively, for adults, whilst the corresponding values for infants and children were between 1-12 years and 70 years, respectively. As a result, the CR for children was lower due to the shorter exposure time. A similar outcome was documented in [28] as well as in [29].

In addition, the results also showed that the fine mode particles were likely to exhibit more potential health effects compared to coarse mode particles for all trace elements at all measurement sites. In this study, the proportions of fine particles have two important implications on the health effects of re-suspended dust episodes. First, fine particles can remain in suspension much longer than coarse particles and can, thus, can result in larger spatial impacts by the re-suspended PM. Secondly, the fine fraction of re-suspended particulate matter is more likely to comprise anthropogenic constituents that are potentially more toxic than the fine particles of purely crustal origin. This study agreed with the reviews by [30-32], which concluded that there tends to be a stronger relation between fine particles, $\mathrm{PM}_{2.5}$ and most health effects than between $\mathrm{PM}_{10}$ and effects on health.

\section{Conclusions}

This study showed that the levels of air quality during the different phases of lockdown were still within the guidelines set by the DOE. Differences in the number of vehicles and industrial activities played an important role in influencing the distribution of pollutant concentrations at each sensor location. The results showed that air pollutants over PJ increased from normal days $>\mathrm{MCO}>\mathrm{RMCO}>\mathrm{MCO} 1>\mathrm{MCO} 2$. However, $\mathrm{KJ}$ recorded air pollutants decreasing during $\mathrm{MCO}$ to $\mathrm{CMCO}$ for $\mathrm{PM}_{10}, \mathrm{PM}_{2.5}, \mathrm{SO}_{2}$ and $\mathrm{O}_{3}$, whilst, during $\mathrm{CMCO}$ to $\mathrm{RMCO}$, there were slight decreases for $\mathrm{PM}_{10}, \mathrm{PM}_{2.5}, \mathrm{SO}_{2}$ and $\mathrm{NO}_{2}$. In $\mathrm{KD}$, a decrease of $\mathrm{PM}_{2.5}$ during $\mathrm{MCO}$ to $\mathrm{RMCO}$ and decreases of $\mathrm{PM}_{2.5}$ and $\mathrm{O}_{3}$ during the $\mathrm{CMCO}$ to RMCO were observed. 
Due to the relaxation of movement controls that were implemented by the government from CMCO to RMCO, there should have been increased air pollutant concentrations due to the increase in the number of vehicles and factories operating. However, most employers still practiced a WFH policy during this period of change. The emissions from vehicles and industrial emissions from $\mathrm{KL}$ and other nearby regions were expected to be the main sources of pollutants during these lockdown phases. The concentrations of air pollutants recorded at the three stations were not influenced by meteorological factors such as temperature and $\mathrm{RH}$ but were more likely influenced by wind direction and wind speed.

The health risk assessment analysis showed that the non-carcinogenic risks due to exposure to $\mathrm{NO}_{2}, \mathrm{SO}_{2}, \mathrm{CO}, \mathrm{O}_{3}, \mathrm{PM}_{10}$ and $\mathrm{PM}_{2.5}$ via the inhalation route at all three locations were unlikely to pose non-carcinogenic effects, except for $\mathrm{SO}_{2}$ in $\mathrm{KJ}(\mathrm{HQ}>1)$, which showed potential for encountering non-cancerous effects of exposure to $\mathrm{SO}_{2}$. Good air quality can be achieved if the number of vehicles on the roads and industrial emissions can be controlled. The use of continuous air quality sensors to measure real-time air pollutant concentrations in urban areas is a step that can be considered for the purpose of air quality control in the future.

Author Contributions: M.S.M.N., M.Z.M.N., F.M., H.H.A.H. and B.A.H. conceptualized the idea; M.S.M.N., M.C.G.O., M.F.F.M.N., M.I.A.W. and S.H.M.A. aided in the study design; M.S.M.N., M.I.A.W., M.K.O. and H.H.A.H. performed the air sampling procedures; M.F.F.M.N. and M.A.A.B., L.H.S., S.M., M.C.G.O. and N.M.A. performed the statistical analysis; Z.K., N.M.A., J.A., G.R.T., N.A.Y. and M.M.M. contributed equally to the data analysis and interpretations. All authors have read and agreed to the published version of the manuscript.

Funding: This research was funded by Ministry of Higher Education Malaysia grant number [PRGS/1/2020/WAB04/UKM/02/1] And Universiti Kebangsaan Malaysia grant number [GGP2019-015] and [GPK-KOM-2020-024].

Institutional Review Board Statement: Not applicable.

Informed Consent Statement: Not applicable.

Data Availability Statement: Copernicus Climate Change Service (C3S) (2017): ERA5: Fifth generation of ECMWF atmospheric reanalyses of the global climate. Copernicus Climate Change Service Climate Data Store (CDS), Date of Access: 10 July 2021. https:/ / cds.climate.copernicus.eu/cdsapp\#!/ home.

Acknowledgments: We would like to thank Ministry of Higher Education Malaysia (MOHE) and Universiti Kebangsaan Malaysia for the Prototype Research Grant Scheme (PRGS) no: PRGS/1/2020/ WAB04/UKM/02/1 and GPK-C19-2020-013. Muhamad Ikram A Wahab would like to thank Universiti Kebangsaan Malaysia (UKM) internal grant registered as GGP-2019-015. Mohd Shahrul Mohd Nadzir would like to thank the Mayor of Petaling Jaya City Council (MBPJ) Dato' Mohd Sayuthi bin Bakar for sensors data and having the great vision to make PJ a smart city and to the rest of the MBPJ staff. Mohd Fadzil Firdzaus Mohd Nor also would like to thank his sponsor, the FIO-UM Joint Center of Marine Science and Technology. This study relied on archived ERA5 data, which was generated using the Copernicus Climate Change Service toolbox in this publication. Finally, we would like to send our appreciation to all of our brave frontliners around the world during the times of crisis.

Conflicts of Interest: The authors declare no conflict of interest.

\section{References}

1. Han, S.; Bian, H.; Feng, Y.; Liu, A.; Li, X.; Zeng, F.; Zhang, X. Analysis of the Relationship between $\mathrm{O}_{3}, \mathrm{NO}$ and $\mathrm{NO}_{2}$ in Tianjin, China. Aerosol. Air Qual. Res. 2011, 11, 128-139. [CrossRef]

2. Collivignarelli, M.C.; Abba, A.; Bertanza, G.; Pedrazzani, R.; Ricciardi, P.; Miino, M.C. Lockdown for COVID-2019 in Milan: What are the effects on air quality? Sci. Total Environ. 2020, 732, 139280. [CrossRef] [PubMed]

3. Ryan, R.G.; Silver, J.D.; Schofield, R. Air quality and health impact of 2019-20 Black Summer megafires and COVID-19 lockdown in Melbourne and Sydney, Australia. Environ. Pollut. 2021, 274, 116498. [CrossRef]

4. New Straits Times. COVID-19: Movement Control Order Imposed with Only Essential Sectors Operating. Available online: https://web.archive.org/web/20200316224520/https://www.nst.com.my/news/nation/2020/03/575177/covid-19 -movement-control-order-imposed-only-essential-sectors-operating (accessed on 16 March 2020). 
5. Mohd Nadzir, M.S.; Ooi, M.C.G.; Alhasa, K.M.; Bakar, M.A.A.; Mohtar, A.A.A.; Nor, M.F.F.M.; Latif, M.T.; Hamid, H.H.A.; Ali, S.H.M.; Ariff, N.M.; et al. The Impact of Movement Control Order (MCO) during Pandemic COVID-19 on Local Air Quality in an Urban Area of Klang Valley, Malaysia. Aerosol Air Qual. Res. 2020, 20, 1237-1248. [CrossRef]

6. Bray, C.D.; Nahas, A.; Battye, W.H.; Aneja, V.P. Impact of lockdown during the COVID-19 outbreak on multi-scale air quality. Atmos. Environ. 2021, 254, 118386. [CrossRef]

7. Mahato, S.; Pal, S.; Ghosh, K.G. Effect of Lockdown amid COVID-19 Pandemic on Air Quality of the Megacity Delhi, India. Sci. Total Environ. 2020, 730, 139086. [CrossRef]

8. Kerimray, A.; Baimatova, N.; Ibragimova, O.P.; Bukenov, B.; Kenessov, B.; Plotitsyn, P.; Karaca, F. Assessing air quality changes in large cities during COVID-19 lockdowns: The impacts of traffic-free urban conditions in Almaty, Kazakhstan. Sci. Total Environ. 2020, 730, 139-179. [CrossRef]

9. Latif, M.T.; Dominick, D.; Hawari, N.S.S.L.; Mohtar, A.A.A.; Othman, M. The concentration of major air pollutants during the movement control order due to the COVID-19 pandemic in the Klang Valley, Malaysia. Sustain. Cities Soc. 2021, 66, 102660. [CrossRef] [PubMed]

10. Hashim, B.M.; Al-Naseri, S.K.; Al-Maliki, A.; Al-Ansari, N. Impact of COVID- 19 lockdown on $\mathrm{NO}_{2}, \mathrm{O}_{3}, \mathrm{PM}_{2.5}$ and PM 10 concentrations and assessing air quality changes in Baghdad, Iraq. Sci. Total Environ. 2020, 754, 141978. [CrossRef]

11. Archer, C.L.; Cervone, G.; Golbazi, M.; Al Fahel, N.; Hultquist, C. Changes in air quality and human mobility in the USA during the COVID-19 pandemic. Bull. Atmos. Sci. Technol. 2020, 1, 491-514. [CrossRef]

12. Abdullah, S.; Abu Mansor, A.; Mohd Napi, N.N.L.; Wan Mansor, W.N.; Ahmed, A.N.; Ismail, M.; Ahmad Ramly, Z.T. Air quality status during 2020 Malaysia Movement Control Order (MCO) due to 2019 novel coronavirus (2019-nCoV) pandemic. Sci. Total Environ. 2020, 729, 139022. [CrossRef]

13. Kanniah, K.D.; Kamarul Zaman, N.; Kaskaoutis, D.G.; Latif, M.T. COVID-19's impact on the atmospheric environment in the Southeast Asia region. Sci. Total Environ. 2020, 736, 139658. [CrossRef] [PubMed]

14. Bauwens, M.; Compernolle, S.; Stavrakou, T.; Müller, J.F.; Van Gent, J.; Eskes, H.; Levelt, P.F.; van der A, R.; Veefkind, J.; Vlietinck, J. Impact of coronavirus outbreak on NO2 pollution assessed using TROPOMI and OMI observations. Geophys. Res. Lett. 2020, 47, e2020GL087978. [CrossRef] [PubMed]

15. Petetin, H.; Bowdalo, D.; Soret, A.; Guevara, M.; Jorba, O.; Serradell, K.; P'erez GarcíaPando, C. Meteorology-normalized impact of COVID-19 lockdown upon $\mathrm{NO}_{2}$ pollution in Spain. Atmos. Chem. Phys. Discuss. 2020, 2, 1-29. [CrossRef]

16. Putaud, J.-P.; Pozzoli, L.; Pisoni, E.; Martins Dos Santos, S.; Lagler, F.; Lanzani, G.; Dal Santo, U.; Colette, A. Impacts of the COVID-19 lockdown on air pollution at regional and urban background sites in northern Italy. Atmos. Chem. Phys. 2021, 21, 7597-7609. [CrossRef]

17. Alhasa, K.M.; Mohd Nadzir, M.S.; Olalekan, P.; Latif, M.T.; Yusup, Y.; Iqbal Faruque, M.R.; Ahamad, F.; Abd. Hamid, H.H.; Aiyub, K.; Md Ali, S.H.; et al. Calibration model of a low-cost air quality sensor using an adaptive neuro-fuzzy inference system. Sensors 2018, 18, 4380. [CrossRef]

18. Bernama. Essence of Conditional Movement Control Order. Available online: https://web.archive.org/web/20200502065534 /https:/ / www.bernama.com/en/general/news.php?id=1837487 (accessed on 1 May 2020).

19. Copernicus Climate Change Service (C3S) (2017): ERA5: Fifth Generation of ECMWF Atmospheric Reanalyses of the Global Climate. Copernicus Climate Change Service Climate Data Store (CDS). Available online: https:/ / cds.climate.copernicus.eu/ cdsapp\#! / home (accessed on 10 July 2021).

20. Suhaimi, N.F.; Jalaludin, J.; Latif, M.T. Demystifying a Possible Relationship between COVID-19, Air Quality and Meteorological Factors: Evidence from Kuala Lumpur, Malaysia. Aerosol Air Qual. Res. 2020, 20, 1520-1529. [CrossRef]

21. Mazzeo, N.A.; Venegas, L.E.; Choren, H. Analysis of NO, NO2, O3 and NOx Concentrations Measured at a Green Area of Buenos Aires City during Wintertime. Atmos. Environ. 2005, 39, 3055-3068. [CrossRef]

22. Jacob, D.J. Introduction to Atmospheric Chemistry; Princeton University Press: Princeton, NJ, USA, 1999.

23. Xue, L.K.; Wang, T.; Gao, J.; Ding, A.J.; Zhou, X.H.; Blake, D.R.; Wang, X.F.; Saunders, S.M.; Fan, S.J.; Zuo, H.C.; et al. Ozone production in four major cities of China: Sensitivity to ozone precursors and heterogeneous processes. Atmos. Chem. Phys. Discuss. 2013, 13, 27243-27285. [CrossRef]

24. Kovač-Andrić, E.; Radanović, T.; Topalović, I.; Marković, B.; Sakač, N. Temporal Variations in Concentrations of Ozone, Nitrogen Dioxide, and Carbon Monoxide at Osijek, Croatia. Adv. Meteorol. 2013, 2013, 469786. [CrossRef]

25. Xiao, K.; Wang, Y.; Wu, G.; Fu, B.; Zhu, Y. Spatiotemporal Characteristics of Air Pollutants (PM10, PM2.5, SO 2 , NO 2 , O 3 , and CO) in the Inland Basin City of Chengdu, Southwest China. Atmosphere 2018, 9, 74. [CrossRef]

26. Ljung, K.; Selinus, O.; Otabbong, E. Metals in soils of children's urban environments in the small northern European city of Uppsala. Sci. Total Environ. 2006, 366, 749-759. [CrossRef] [PubMed]

27. Acosta, J.A.; Faz Cano, A.; Arocena, J.M.; Debela, F.; Martínez-Martínez, S. Distribution of metals in soil particle size fractions and its implication to risk assessment of playgrounds in Murcia City (Spain). Geoderma 2009, 149, 101-109. [CrossRef]

28. Iqbal, S.; Law, H.Z.; Clower, J.H.; Yip, F.Y.; Elixhauser, A. Hospital burden of unintentional carbon monoxide poisoning in the United States, 2007. Am. J. Emerg. Med. 2012, 30, 657-664. [CrossRef]

29. Wang, C.; Bi, J.; Olde Rikkert, M.G.M. Early warning signals for critical transitions in cardiopulmonary health, related to air pollution in an urban Chinese population. Environ. Int. 2018, 121, 240-249. [CrossRef] 
30. Pope, C.A.; Dockery, D.W. Health effects of fine particulate air pollution: Lines that connect. J. Air Waste Manag. Assoc. 2006, 56, 709-742. [CrossRef]

31. Schlesinger, R.B. The Health Impact of Common Inorganic Components of Fine Particulate Matter (PM2.5) in Ambient Air: A Critical Review. Inhal. Toxicol. 2007, 19, 811-832. [CrossRef]

32. Bello, S.; Muhammad, B.G.; Bature, B. Total excess lifetime cancer risk estimation from enhanced heavy metals concentrations resulting from tailings in Katsina Steel Rolling Mill, Nigeria. J. Mater. Sci. Eng. 2017, 6, 338. 